\title{
ASPECTS OF THE TROPHIC NICHE OF MELIPONA MARGINATA MARGINATA LEPELETIER (APIDAE, MELIPONINAE)
}

\author{
A. KLEINERT-GIOVANNINI and V.L. IMPERATRIZ-FONSECA \\ Departamento de Ecologia Geral do Instituto de Biociĉncias da Universidade de São Paulo, \\ 05508, São Paulo. Brasil.
}

\begin{abstract}
SUMMARY
Pollen and honcy samples were colleted once every two weeks from the food pots of two colonies of Melipona marginata marginata Lepeletier for a twelve-month period (August/1981 to July/1982).

Altogether, 173 pollen types were found, belonging to 38 plant families in the samples from both colonies, although the really important sources (with representation of $10 \%$ or over) for good collection were represented by only 11 plant species ( 9 in pollen samples and 8 in honcy samples) belonging to six families. An interesting point is that from all the visited plant species, the most represented in both type of samples were trees.

The plant families which occured most in pollen samples were: Myrtaccae, Solanaceac, Melastomataceae, and Leguminosae. In honey samples, the same sequence was observed, but the last two families appeared in the opposite order.

The niche size as indicated by the number of pollen types fails to highlight the relative importance of plant species visited for food and assumes utilization of resources to be homogeneous.

As regards niche size, as calculated by Suannon-Weaver's diversity index, both colonics had lower values than any other bee species in the same area and used the sources visited least homogeneously.

Summer was the season when both colonies showed the greatest similarity in terms of the sources visited for pollen. As far as honey samples are concerned, autumn and early winter were the times when the two colonics overlapped most.
\end{abstract}

\section{INTRODUCTION}

The basic ideas concerning trophic niche theory come from Darwin (1859) and his detailed discussion of the possibility that ecologically related forms can coexist. Darwin pointed out that species belonging to the same genus commonly show great similarity of habits and constitution, so that if there is 
competition between them, it is far more acute than competition between species of different genera.

The modern concept of niche, formulated by Hutchinson (1957) and broadened by Levins (1968), MacArthur (1968), VAndermeer (1972) and PIANKA (1976), considers that every measurable feature of the environment can be associated with a coordinate in a hyperspace with $\mathbf{n}$ dimensions. An organism's niche is the region of this space in which its fitness is positive. In other words, niche is no more than a hypervolume with $\mathrm{n}$ dimensions, where the axes are biotic and abiotic critical factors which determine the existence of species. Levins (1968) stresses that the only axes, or niche dimensions, which should be considered are the variables which serve to separate species, and along which species can be ranked in series.

Melipona marginata has been chosen for the present analysis for a number of reasons. The first has do to with the low representativity of bees of the genus Melipona in the samples of relative abundance obtained so far (KNOLL, 1985). Before the introduction of Apis, these bees were important honey producers. A second reason is the fact that the introduction of the African bee into Brazil coincided with the beginning of intense deforestation in most of the country: this led to microclimatic changes and reduced the availability of suitable sites for nidification by bees which almost exclusively nest in tree hollows, as in the case of this genus.

In South and Central America, before the impact caused by the introduction of the African honeybee (Apis mellifera adansonii) and the resulting spread of africanized honeybees, no study of resource sharing by the communities had been made. The ecological success of africanized bees was undoubtedly responsible for the excellent studies resources sharing among the stingless bees of Costa Rica by Johnson and Hubbell $(1974,1975)$ and HubBel and JoHnson $(1977,1978)$, while Roubik $(1978,1979,1980)$ attempted to analyse the impact of the africanized bee's arrival on the native social bee community of French Guiana.

The methodologies used in the study mentioned above included observation, counting and collecting bees when visiting flowers, and sugar baits sweetened to different degrees. Another way of determining what food sources bees use is pollen analysis of the material collected by them, as has been done by Absy and Kerr (1977) ; Iwama and Melhem (1979) ; Absy et al. (1980) ; ENGEL and Dingemans-BAKels (1980) ; SommeiJer et al. (1983) ; IMPERATrizFONSECA et al. (1984); KERR et al. (1984) in respect to several species of stingless bees. These authors focused their study on the botanical aspect while Cortopassi-Laurino (1982), Mouga (1984) and Ramalho et al. (1985) dealt more broadly with the problem of the trophic niches occupied by bees, using 
parameters which indicated the degree of diversity and overlap in the resources used.

The aim of the study was to identify the food sources (pollen and nectar) used by Melipona marginata marginata Lepeletier by means of pollen analysis. The data obtained were used to determine the trophic niche size, evenness index and percentage overlap of the two colonies considered.

\section{MATERIAL AND METHODS}

Samples of pollen (3-4 g per sample) and honey (6-7 g per sample) were collected from the newly constructed food pots of two colonies of Melipona marginata marginata Lepeletier $\left(\mathrm{M}_{1}\right.$ and $\left.\mathrm{M}_{2}\right)$ once every two weeks for a year (August 1981 to July 1982). Altogether, 95 samples were taken, 48 samples of honey (24 from each colony) and 47 of pollen ( 24 from colony $M_{1}$ and 23 from colony $M_{2}$ ).

The colonies were kept in rational hives (Nogueira-Neto, 1970) in the Bee Laboratory of the General Ecology Department, Bioscience Institute, University of São Paulo. The area around the Bioscience Institute has diversified native and foreign plant species and a small semi-deciduous forest of native species (approximately 10 hectares) (RamalHo et al., 1985).

Each pollen sample was submitted to the acetolysis process according to ErdTMan's method (1960). The technique used for the honcy samples was that described by Louveaux et al. (1970), as modified by Iwama and Melhem (1979).

Three slides were prepared for each sample, and the material was identified in terms of the morphological characteristics of the pollen grains. It was then compared with the existing material in the reference slide collection housed in the Bee Laboratory and with specialized literature, in an attempt to reach an identification at the level of spccics.

The frequency with which pollen types were represented was determined by counting about 1000 pollen grains in each sample (VERGERoN, 1964). The percentage obtained for the fortnightly samples were added up in order to obtain the monthly pollen spectrum of each of the colonies studied. A note was made of the pollen types which were not counted but were seen to be present in the samples; the notes were used when calculating and analysing the results.

Based on the data for pollen spectra, a number of ecological parameters related to the trophic niches of these bees were calculated :

a) Trophic niche size: this parameter was determined both by the monthly total for pollen types found and by the percentage for each pollen types in the samples. This latter datum was calculated using ShanNon-Weaver's diversity index (1949):

$$
H^{\prime}=-\sum_{i=1}^{n} \text { pi.ln pi }
$$

pi $=$ proportion of each pollen type found in samples of colony in question during month considered. ln = natural logarithm.

b) Evenness : this parameter indicates the degree of gathering uniformity among the various plant species vistied by the colonies during the month considered; it was reached by the following formula (PIELOU, 1977) :

$$
\mathbf{J}^{\prime}=\frac{\mathbf{H}^{\prime}}{\mathbf{H}^{\prime} \max }
$$

$\mathrm{H}^{\prime}$ max. = In of the total number of pollen types present in the samples. The index may vary from 0 to 1 , i.e. from heterogeneous utilization of resources to homogeneous use. 
c) Trophic niche overlap : two indices were used for this calculation :

$c_{1}$ - The first index (Schoener, 1968) takes the proportions of the various pollen types found in the samples to indicate the percentage similarity of food gathering between the two colonies each month :

$$
\text { PS }=1-\frac{1}{2} \Sigma\left|p i_{M_{1}}-p i_{M_{2}}\right|
$$

$\mathrm{pi}_{\mathrm{M}_{1}}=$ proportion of the $\mathrm{i}$ sources visited by colony $\mathrm{M}_{1}$ in the month considered.

$\mathrm{pi}_{\mathrm{M}_{2}}=\mathrm{idem}$ for colony $\mathrm{M}_{2}$.

$c_{2}$ - The second index (CoDy, 1974) takes the number of plant species found in the samples but does not consider their representativity :

$$
\mathrm{a}_{\mathrm{M}_{1} \mathrm{M}_{2}}=\mathrm{n}_{\mathrm{M}_{1} \mathrm{M}_{2}} /\left(\mathrm{n}_{\mathrm{M}_{1}} \cdot \mathrm{n}_{\mathrm{M}_{2}}\right)^{1 / 2}
$$

$\mathrm{n}_{\mathrm{M}_{1} \mathrm{M}_{2}}=$ number of pollen types common to colonies $\mathrm{M}_{1}$ and $\mathrm{M}_{2}$ in month considered.

$n_{M 1}=$ total number of pollen types found in samples of colony $M_{1}$ in month considered.

$\mathrm{n}_{\mathrm{M}_{2}}=\mathrm{idem}$ for colony $\mathrm{M}_{2}$.

The results were statistically analyzed to find the degree of correlation between the various parameters calculated, and to sec whether there were any differences between the two colonies studied. The coefficient used to calculate the correlations was Pearson's, and the differences were determined using Student's t-test.

\section{RESULTS}

During the twelve-month collecting period, 173 pollen types were found in the pollen and honey samples taken from Melipona marginata marginata, belonging to 32 different plant families. Of these, 105 were used to collect pollen and 124 to collect nectar.

As for the colonies taken in isolation, colony $M_{1}$ visited 121 plant species, 76 to gather pollen and 87 to gather nectar. In the samples from colony $\mathrm{M}_{2}$ 120 pollen types were found, 74 of them in the pollen samples and 91 in the honey samples.

The $10 \%$ lower limit was considered the point at which the plant species found in samples began to acquire importance for the bees as a source of food (Ramalho and Kleinert-Giovannini, in press.).

Tabl. 1 shows a list of the pollen types which appeared in the honey and pollen samples from the two colonies with percentages of more than $1 \%$. Those with more than $10 \%$ representativity are shown in parentheses. It can be seen that during the twelve-month collecting period only 26 pollen types ( 14 in the pollen samples and 26 in the honey samples), belonging to 15 plant families, were found with percentages of more than $1 \%$. Of these 26 , only 11 types ( 9 in the pollen samples and 8 in the honey samples), belonging to six families, had over $10 \%$ representativity. 


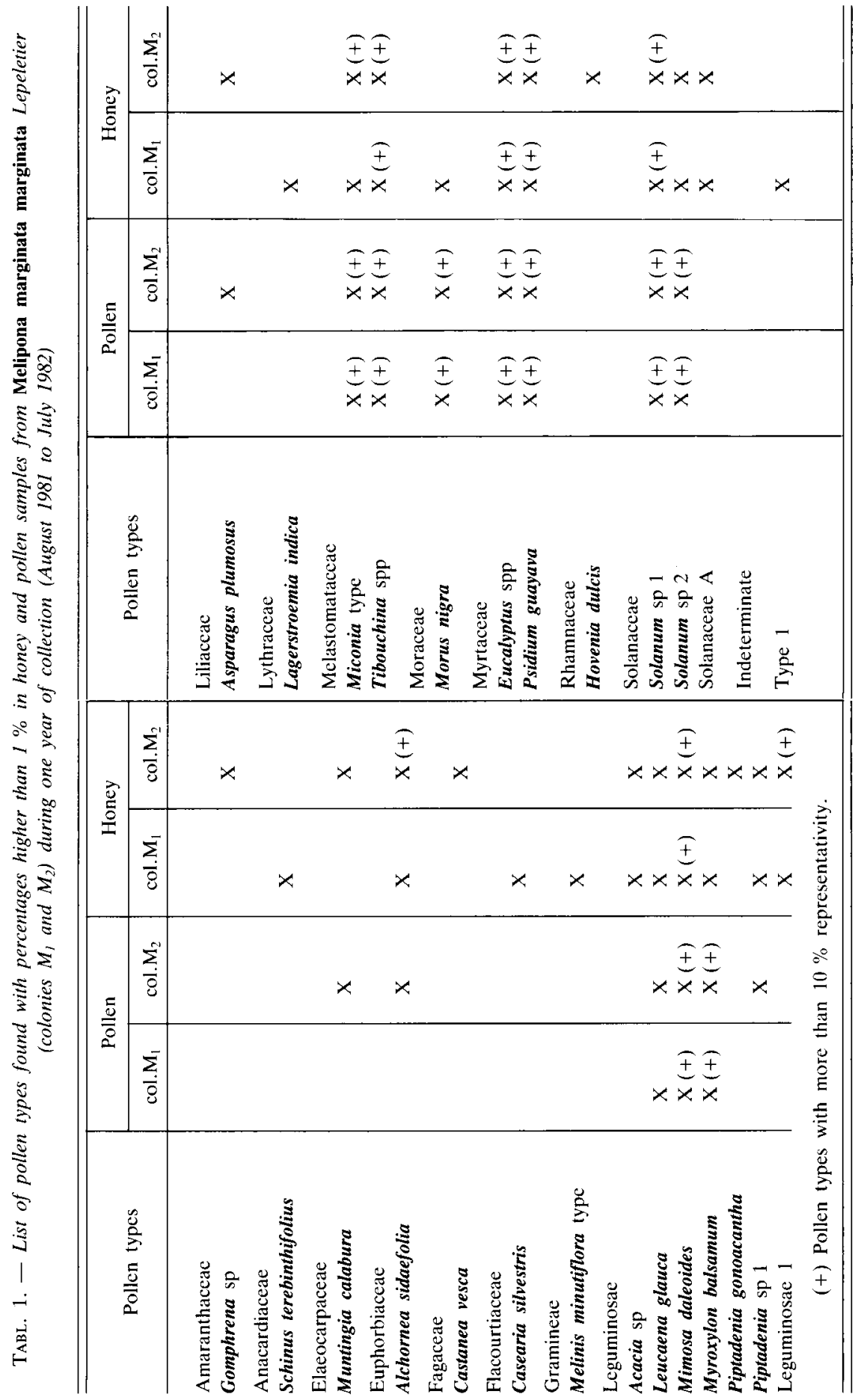




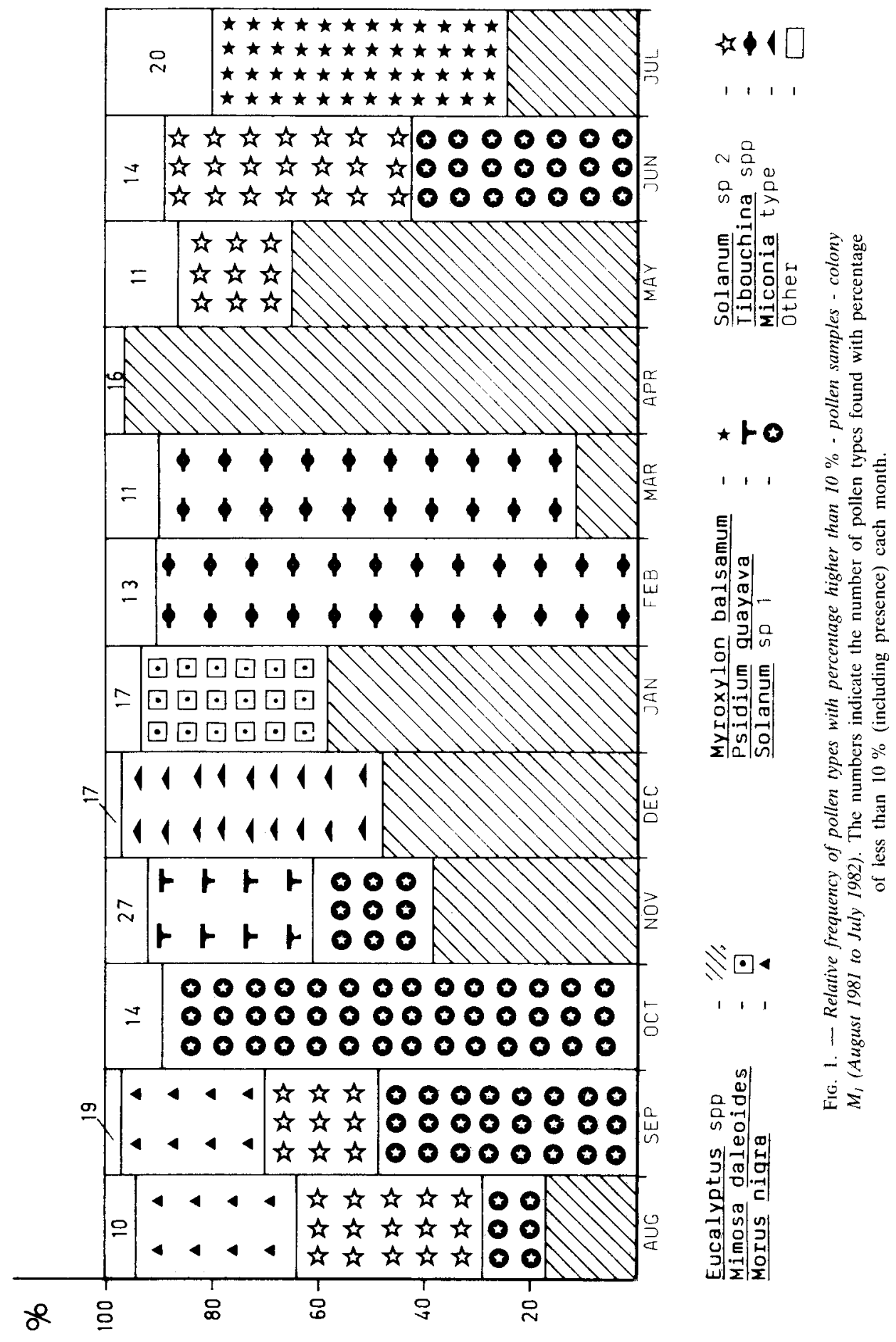




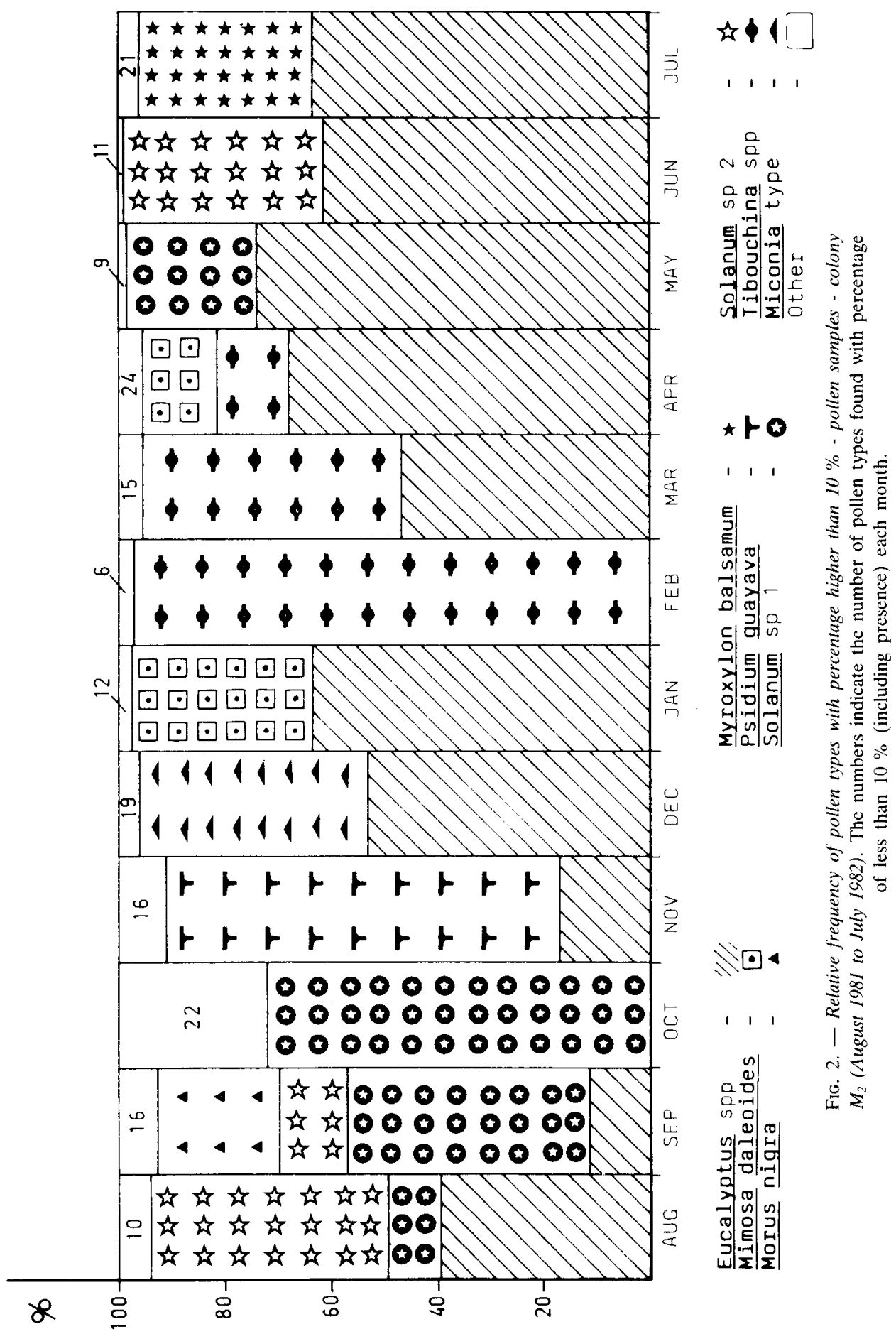


Fig. 1, 2 show the results for percentages of plant species visited by colonies $\mathrm{M}_{1}$ and $\mathrm{M}_{2}$ respectively for pollen collection. In both colonies the same nine pollen types appeared with more than $10 \%$, and only the monthly representativity in the samples varied: Eucalyptus spp, Psidium guayava, Solanum sp 1, Solanum sp 2, Tibouchina spp, Miconia type, Mimosa daleoides, Myroxylon balsamum, and Morus nigra.

It can be seen that Eucalyptus spp was a major genus for pollen gathering in both colonies, as it was well represented in almost all months of the year, especially in samples from colony $\mathrm{M}_{2}$. Another species from the same family (Myrtaceae), Psidium guayava, was important for pollen gathering only in November, and was also more visited by colony $\mathrm{M}_{2}$.

Another well-represented genus was Solanum, with two species : one of these ( $\mathrm{sp} \mathrm{1)}$ was the dominant species in October for both colonies. This genus appeared with representative percentages in samples in August, September, October, November, May and June.

The family Melastomataceae was represented by Tibouchina spp and by the pollen type named Miconia. The former genus appeared with high percentages in February and March, both in colony $\mathbf{M}_{1}$ and $\mathbf{M}_{2}$. Its least significant occurence was in March for colony $\mathbf{M}_{2}$. As for Miconia type, it appeared in the histograms for both colonies only in December 1981.

Mimosa daleoides and Myroxylon balsamum represented the family Leguminosae in the pollen samples from both colonies. In January, the former species occured with similar percentages for colony $\mathrm{M}_{1}$ and colony $\mathrm{M}_{2}$, and was also found in April in $\mathbf{M}_{2}$. The second species was found in July, and occurred in colony $M_{1}$ with a higher percentage.

The last family represented in the pollen samples with more than $10 \%$ representation was the family Moraceae, with one species Morus nigra, present in August and September in colony $\mathbf{M}_{1}$, and only in September in colony $\mathbf{M}_{2}$.

The number of pollen types appearing with less than $10 \%$ varied from 10 to 27 in the samples from colony $M_{1}$, and from 6 to 24 in those from $M_{2}$; the 10 to 20 bracket was the most frequent in both colonies.

Fig. 3, 4 show the monthly pollen spectrum for the honey samples from colonies $\mathrm{M}_{1}$ and $\mathrm{M}_{2}$ respectively. Five plant species were found with more than $10 \%$ representation in colony $\mathbf{M}_{1}$, whereas in $\mathbf{M}_{2}$ there were eight such species. The following pollen types were common to both colonies : Eucalyptus spp, Psidium guayava, Solanum sp 1, Tibouchina spp, and Mimosa daleoides. Colony $\mathrm{M}_{2}$ contained three further pollen types in addition to the latter five : Alchornea sidaefolia, Leguminosae 1, and Miconia type. 


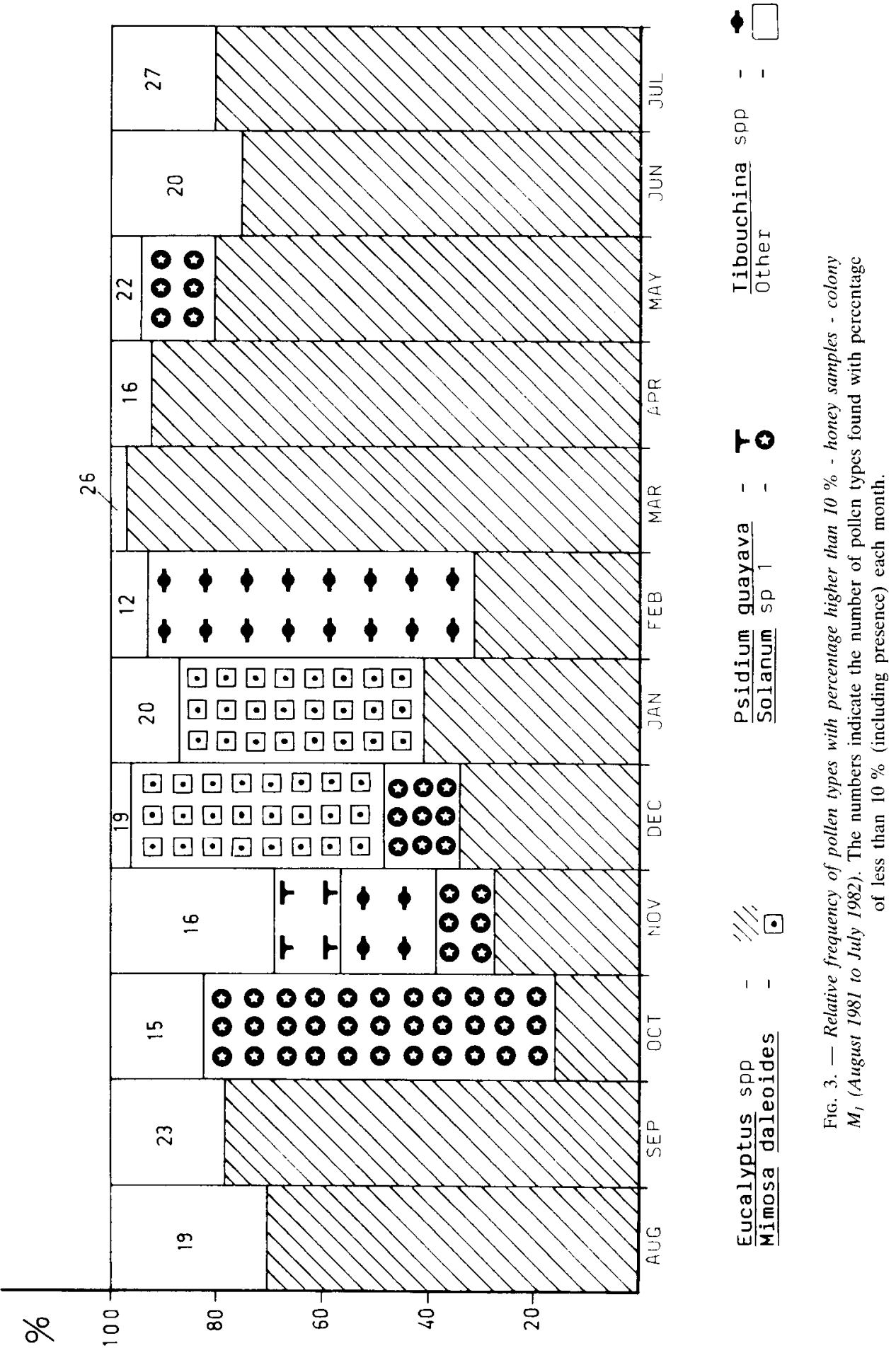




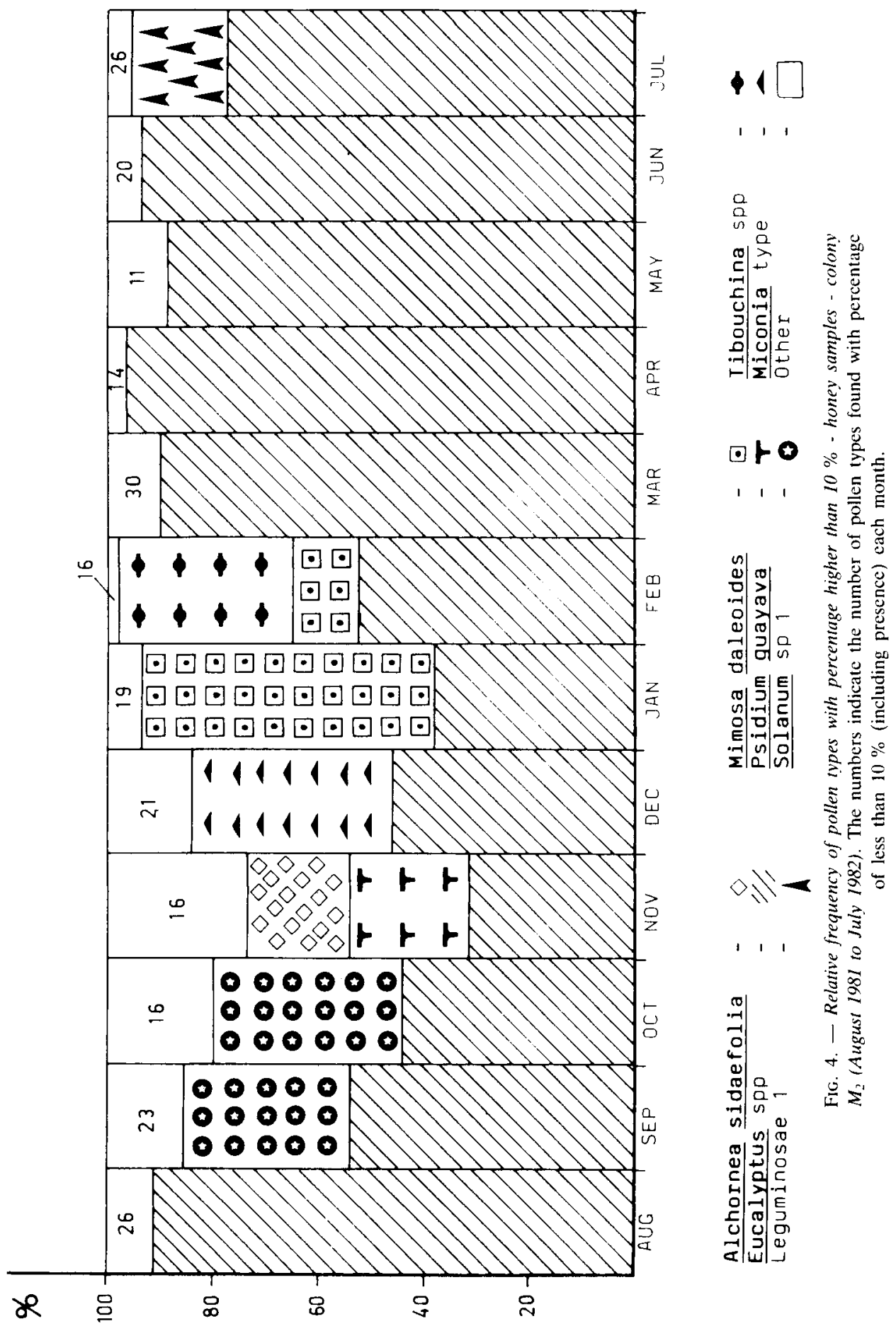


As observed for the pollen samples, pollen types which were not represented in the monthly pollen spectrum of a colony were always found with percentages of less than $10 \%$ in samples from the other colony.

Eucalyptus spp was found in all months of the year in both colonies; it appeared with more than $50 \%$ in August and September 1981, and from March to July 1982, and was found in February 1982 in colony $\mathbf{M}_{2}$. Psidium guayava, which was present in the pollen samples for November in both colonies, was also only visited in November for nectar gathering, although its representation was lower, especially in samples from colony $\mathbf{M}_{2}$.

In the honey samples, the family Solanaceae was represented by a single species (Solanum sp 1). In colony $\mathrm{M}_{1}$, this species was found in October, November, December and May, while in $M_{2}$ it was found in September and October.

In samples from colony $\mathbf{M}_{1}$, the family Melastomataceae had only one representative, Tibouchina spp; this genus was visited in February for both nectar and pollen and in November only for nectar. In samples from colony $\mathbf{M}_{2}$, in addition to Tibouchina spp, which was found only in February, the same pollen type as that found in pollen samples in December, Miconia type, was found in the honey samples for the same month.

Mimosa daleoides, which represented the family Leguminosae in both colonies, was important for nectar gathering in December and January in colony $\mathbf{M}_{1}$, and in January and February in colony $\mathbf{M}_{2}$, although in the latter month it appeared with relatively low representation. Another member of the same family, known as Leguminosae 1 , only occurred in colony $\mathbf{M}_{2}$ in July 1982.

One family not represented in pollen samples but found with more than $10 \%$ representativity in honey samples was the family Euphorbiaceae. One species in the family, Alchornea sidaefolia, was found in November only in colony $\mathrm{M}_{2}$.

It can be seen that the number of pollen types with less than $10 \%$ representation was significantly higher in honey than in pollen samples throughout the year, showing that bees visited a larger number of plant species for nectar gathering purposes, until they settled down with one or a few species which could provide for their needs.

The plant family with most species represented in samples, both pollen and honey, was Leguminosae, followed by Compositae, Euphorbiaceae and Myrtaceae (Fig. 5). If the percentage occurence is considered, although the family Leguminosae occupied the top position as regards the number of representatives, Myrtaceae was most visited for both pollen and nectar, above 

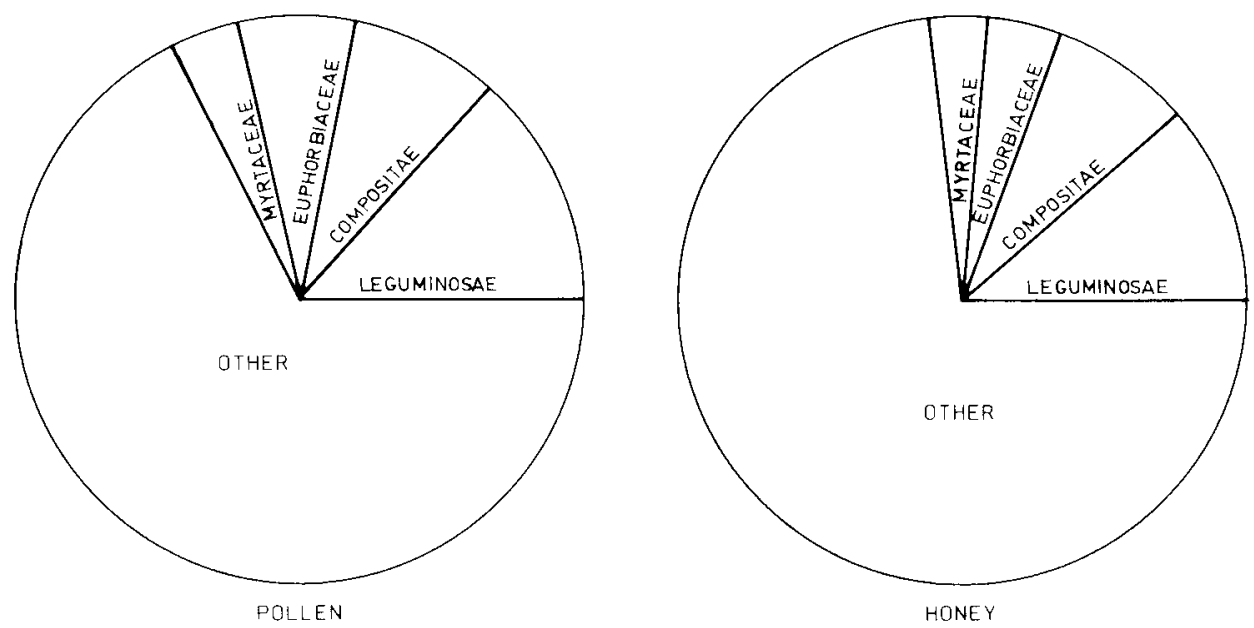

FIG. 5. - Pie diagram of the most represented plant families in Melipona marginata marginata samples (in number of species).

all for the latter. Of the species belonging to this family, Eucalyptus spp accounted for $88.5 \%$ of the total percentage occurence in pollen samples, and for $97.4 \%$ in honey samples, as can be seen in Fig. 6. In both types of sample, the second most visited family was Solanaceae, with a higher percentage occurence in pollen samples. The next most visited families were Melastomataceae and Leguminosae for pollen, with these same families in the reverse order for the honey samples.
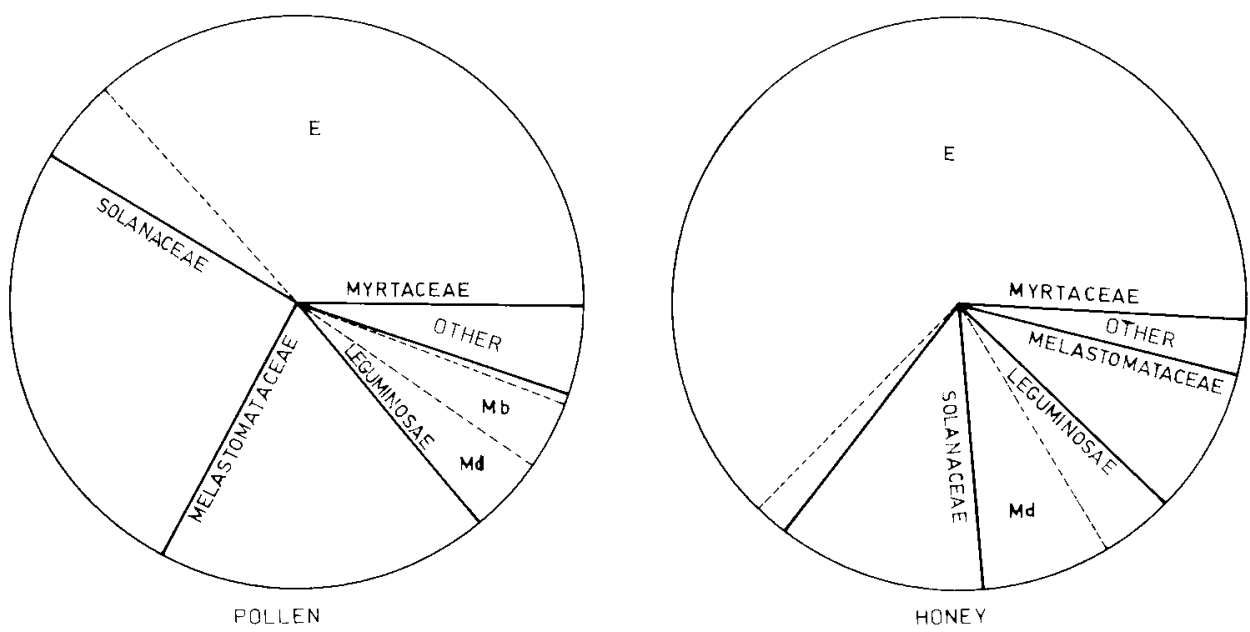

FIG. 6. - Pie diagram of the most represented plant families in Melipona marginata marginata samples (in frequency). $\mathrm{E}=$ Eucalyptus spp. $\mathrm{Md}=$ Mimosa daleoides. Mb $=$ Myroxylon balsamum. 
The family Leguminosae was not important in percentage terms, especially in pollen samples. Here, two plants species alone accounted for virtually all the occurences of this family: Mimosa daleoides $(48.3 \%)$, and Myroxylon balsamum $(43.4 \%)$. The rest corresponded to pollen collected from the other 12 pollen types belonging to this family. In honey samples, Mimosa daleoides accounted for $64.5 \%$ of the total representation of the family Leguminosae, while the remaining $35.5 \%$ were shared among the other plant species belonging to this family and found to be present.

Fig. 7 shows the monthly trophic niche size in relation to pollen gathering, as indicated by the number of plant species visited. November was the month when the highest number of plant species visited by colony $M_{1}$ was found (30), and the lowest value (13) was found in March and May. Comparing individual months, it can be seen that, except for November, there was an absence of pronounced variation in the number of pollen types observed, in contrast with the findings for colony $\mathrm{M}_{2}$, where variation was greater. $\mathrm{M}_{2}$ visited the largest number of plant species in April (27), and the smallest in February (7). Generally speaking, however, the two curves are similar, and the differences found between the values were not statistically significant $(\mathrm{P}>0.99)$.

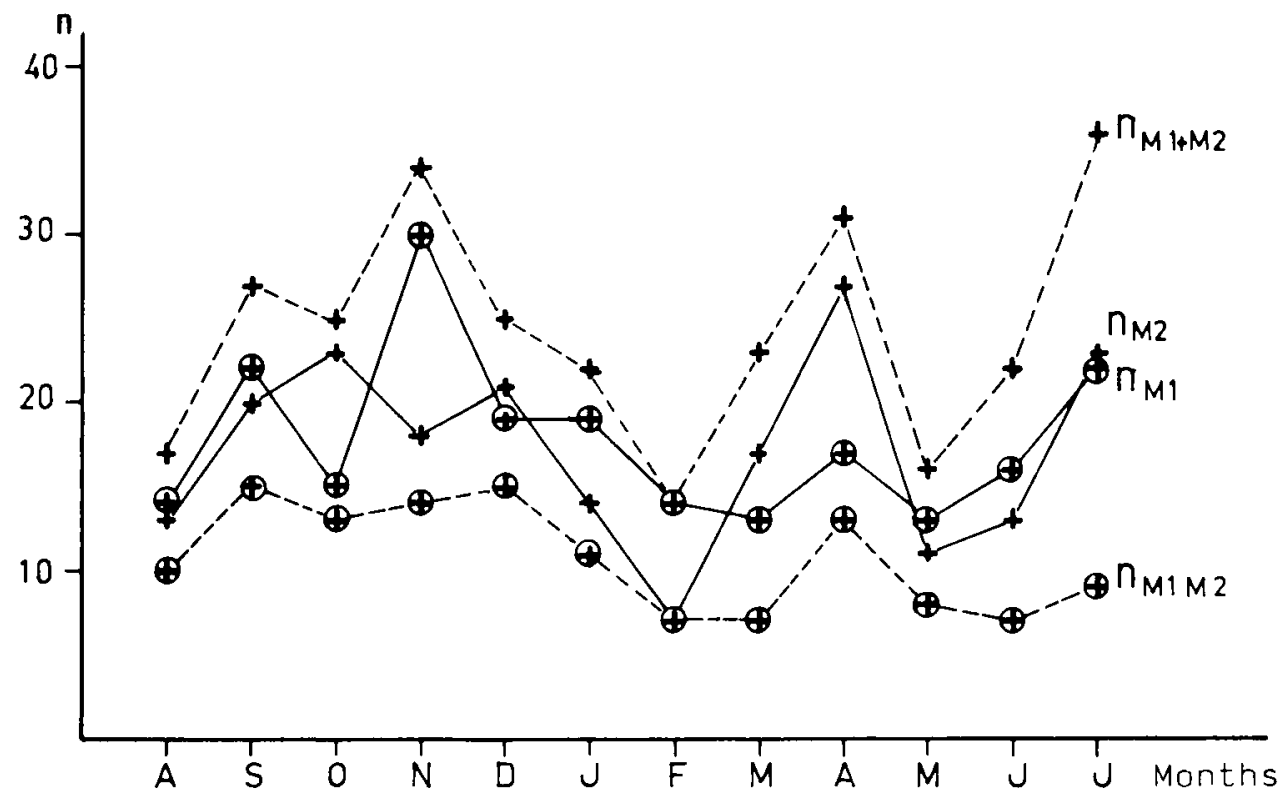

FIG. 7. - Monhly trophic niche size of Melipona marginata marginata as indicated by number of pollen types $(n)$ found in pollen samples.

$n_{M_{1}} \quad$ - number of pollen types in colony $M_{1}$.

$n_{M_{2}} \quad$ - number of pollen types in colony $M_{2}$.

$n_{M_{1} M_{2}}$ - number of pollen types common to both colonies.

$\mathrm{n}_{\mathrm{M}_{1}+\mathrm{M}_{2}} \quad$ - total number of polken types found in samples from both colonies. 
This figure also shows the number of pollen types cummon to the two colonies, and the total number of resources used by both over the whole period. It can be seen that the number of plant species common to both colonies was always less than the number of pollen types found for each colony. This number was the same as the value for colony $\mathrm{M}_{2}$ only in February. These data indicate a difference in the food sources visited each month by colonies $M_{1}$ and $M_{2}$ for pollen gathering. In February, evidently, all the plant species present in the samples from $M_{2}$ were represented in samples from colony $\mathrm{M}_{1}$.

The highest values for the food sources which were common to both colonies were found in September and December (15), while the lowest were found in February, March and June (7).

The curve showing the total number of plant species visited by both colonies had three peaks, one in November (34), a second in April (31), and a third in July (36). The lowest value was February (14).

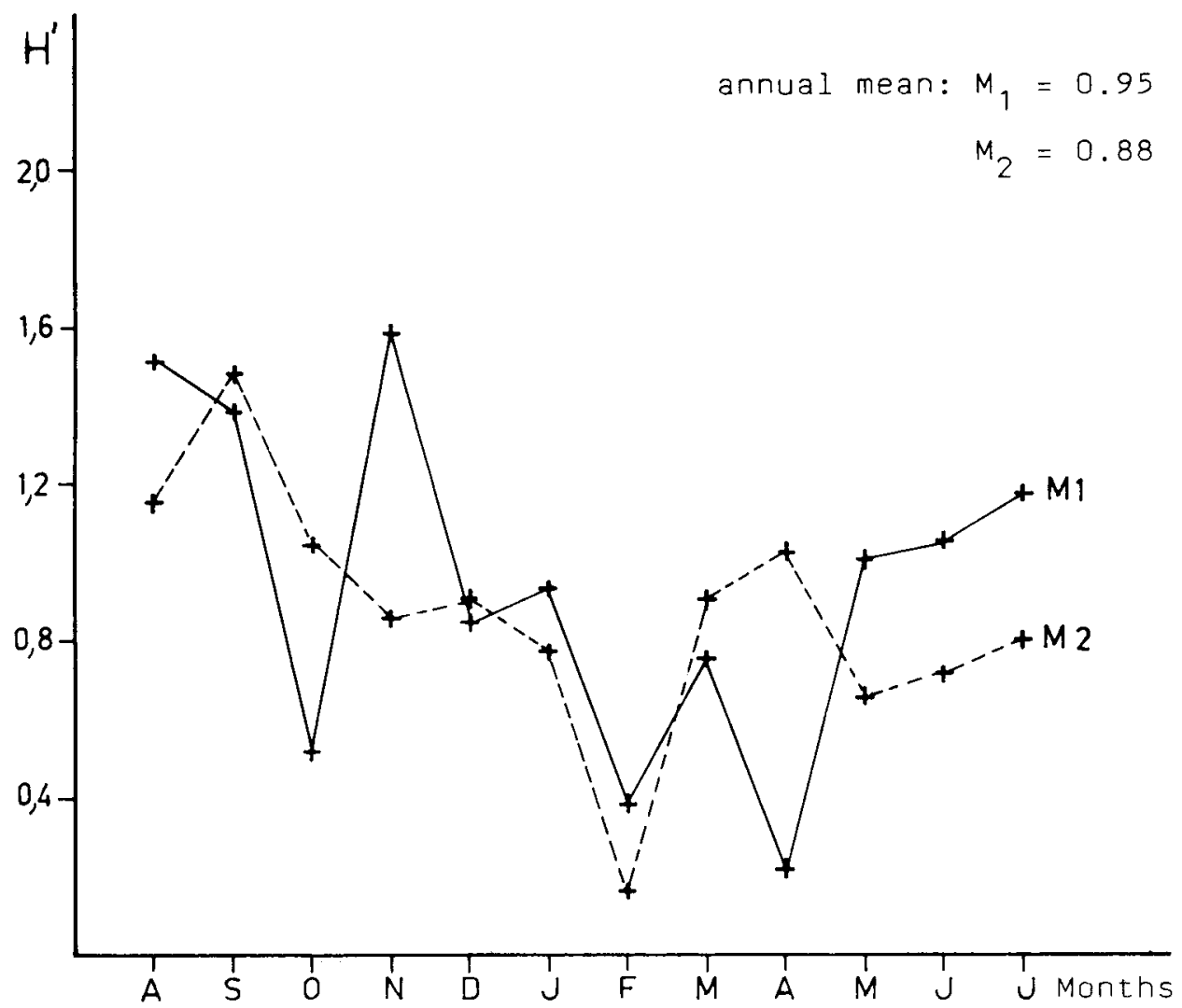

Fic. 8. - Monthly trophic niche size for both colonies of Melipona marginata marginata as calculated by SHANNON-WEAVER'S $\left(H^{\prime}\right)$ - pollen. 
The niche size, calculated using Shannon-Weaver's diversity index $\left(\mathrm{H}^{\prime}\right)$ takes into account the proportion of pollen types found in samples, indicating a greater specifity of foraging as $\mathrm{H}^{\prime}$ diminishes. The indices calculated for both colonies showed no statistically significant differences $(P>0.99)$ between the pairs of monthly values or between annual means (Fig. 8). It can be seen however that the highest values found for $M_{1}$ were for August and November, while the lowest foraging diversity was found in April. For $\mathbf{M}_{2}$, diversity reached a peak in September and gradually fell to its lowest value, which was for February. In March, diversity increased compared with the preceding mongh, and remained more or less constant in the following months.

No significant correlation $(r=0.45 ; P>0.05)$ was found between the values calculated by the two methods for colony $M_{1}$. In other words, there was no correspondence between the number of pollen types present in samples (n) and the degree of diversity shown by bees' visits to flowers $\left(\mathrm{H}^{\prime}\right)$. For colony $\mathrm{M}_{2}$, however, the correlation was positive and significant $(\mathrm{r}=0.91 ; \mathrm{P}<0.05)$.

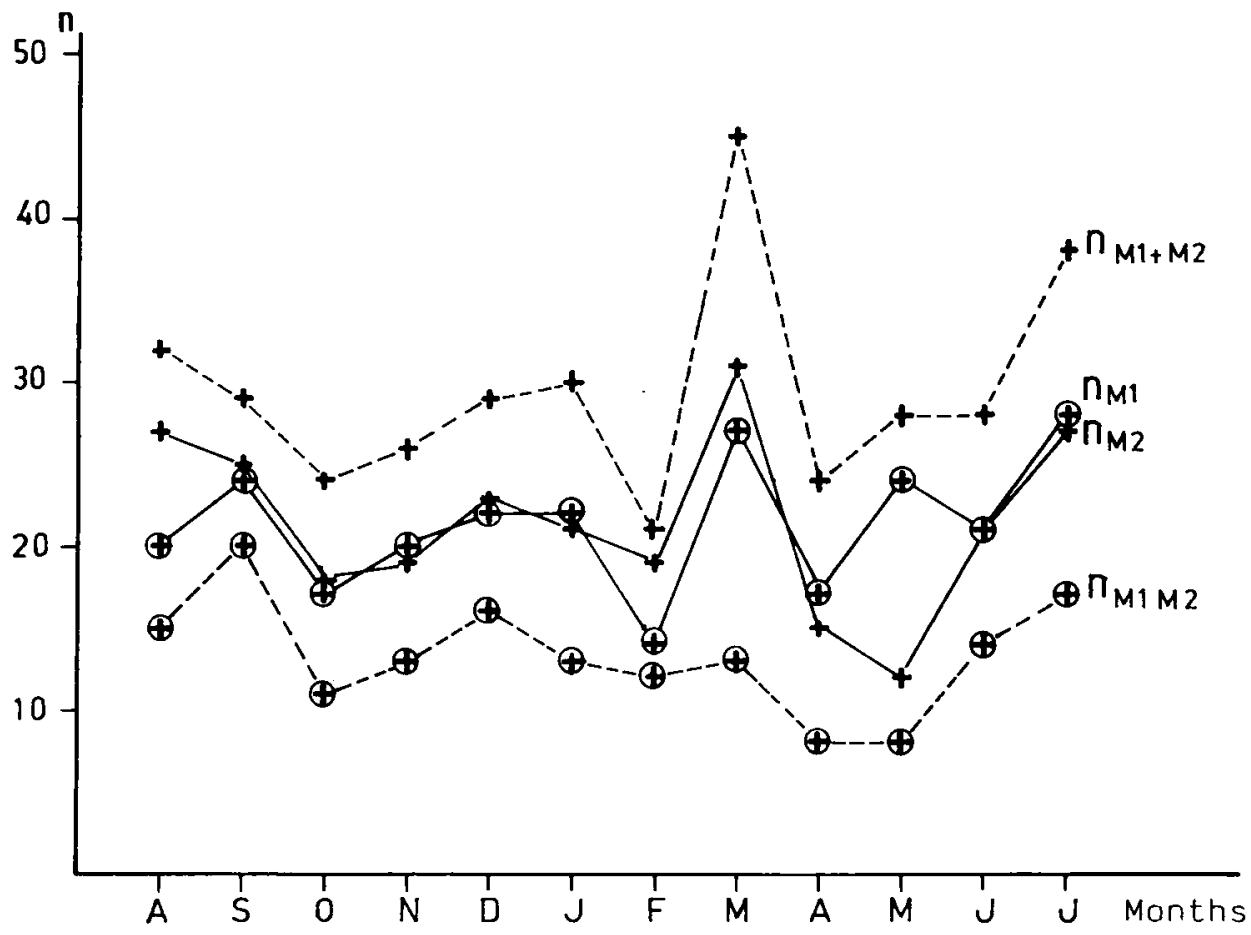

FIG. 9. - Monthly trophic niche size of Melipona marginata marginata as indicated by number of pollen types (n) found in honey samples.

\footnotetext{
$n_{M_{1}} \quad$ - number of pollen types in colony $M_{1}$.

$n_{M_{2}} \quad-$ number of pollen types in colony $M_{2}$.

$n_{M_{1} M_{2}}$ - number of pollen types common to both colonies.

$n_{i M_{1}+M_{2}} \quad$ - total number of pollen types found in samples in both colonies.
} 
In honey samples, the monthly niche size, indicated by the number of plant species found in each colony, was almost always bigger than for the pollen samples, showing that the bees foraged from a larger number of plant species when collecting nectar (Fig. 9). The lowest number of pollen types was found in February (14) for colony $M_{1}$, and the highest in July (28). Colony $M_{2}$ visited the lowest number of plant species in May (12) and the highest in March (31).

A certain correspondence can be observed between the monthly values obtained for the two colonies, with the pronounced exception of May, when colony $M_{1}$ visited twice as many plant species as $M_{2}$. Statistically speaking, however, no significant difference was found $(P>0.99)$ between the monthly values for the colonies.

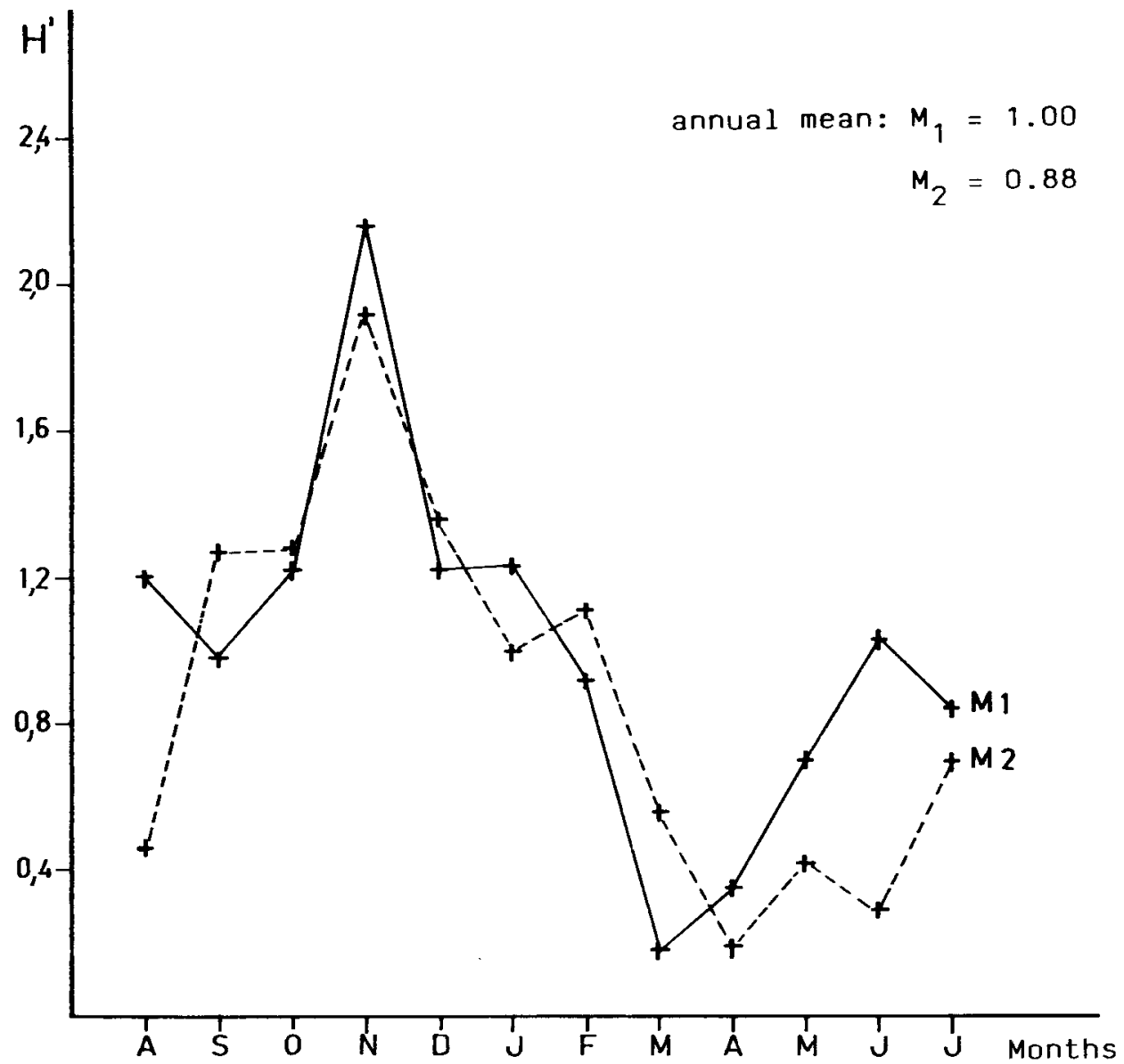

FIG. 10. - Monthly trophic niche size of Melipona marginata marginata as calculated by ShanNon-WEAVER's index $\left(H^{\prime}\right)$ - honey. 
In Fig. 10, which shows the values for niche size calculated according to ShanNON-Weaver's index $\left(\mathbf{H}^{\prime}\right)$, it can be seen that the highest diversity occured in November for both colonies. Colony $\mathbf{M}_{1}$ foraged with least diversity in March and colony $M_{2}$ in April.

A comparison between Fig. 9 and 10 highlights the fact that although the number of plants species found in each colony in March was large, the diversity index $\left(H^{\prime}\right)$ was low, especially for colony $M_{1}$, which concentrated foraging almost exclusively on Eucalyptus spp.

The number of pollen types common to both colonies reached its maximum in September (20) and its minimum in April and May (18). The curve showing the total number of plant species visited by both colonies reached its peaks in March, when 45 pollen types were found. The lowest value occurred in February (21).

Similarity to the pollen samples, no significant differences were found $(P>0.99)$ between the pairs of monthly values for the colonies, or between the annual means of these values. The correlation between the values for niche size calculated by the two methods was not significant for either of the two colonies studied (colony $\mathrm{M}_{1}: \mathrm{r}=-0.50 ; \mathrm{P}>0.05 ;$ colony $\mathrm{M}_{2}: \mathrm{r}=-0.003$; $P>0.05)$.

Fig. 11 shows the values for evenness $\left(\mathrm{J}^{\prime}\right)$ obtained with regard to pollen gathering. Both colonies visited plant species most uniformly in August. Colony $M_{1}$ used resources most heterogeneously in April, while the month in which $\mathrm{M}_{2}$ did so was February.

It can be seen that the curves for the two colonies are relatively similar, and no significant differences were found $(P>0.99)$ either between the pairs of values or between the annual means.

There was a positive and significant correlation between niche size $\left(\mathrm{H}^{\prime}\right)$ and evenness $\left(\mathrm{J}^{\prime}\right)$, both for colony $\mathrm{M}_{1}(r=0.94 ; P<0.05)$ and for colony $\mathrm{M}_{2}$ ( $\mathrm{r}=0.89 ; \mathrm{P}<0.05)$.

Both colonies visited resources used for nectar gathering most homogeneously in November (Fig. 12). The same values were found in March for colony $M_{1}$ and April for $M_{2}$.

The curves plotted for the values of $\mathrm{H}^{\prime}$ and $\mathrm{J}^{\prime}$ with regard to each colony are very similar, with coincinding maxima and minima, as can be seen from a comparison of the two (Fig. 10 and 12). There was a positive and significant correlation between the values of $H^{\prime}$ and $J^{\prime}$, both for colony $M_{1}(r=0.99$; $P<0.05)$ and for colony $M_{2}(r=0.99 ; P<0.05)$. There were no statistically significant differences between the evenness indices calculated for the two colonies $(\mathrm{P}>0.99)$. 


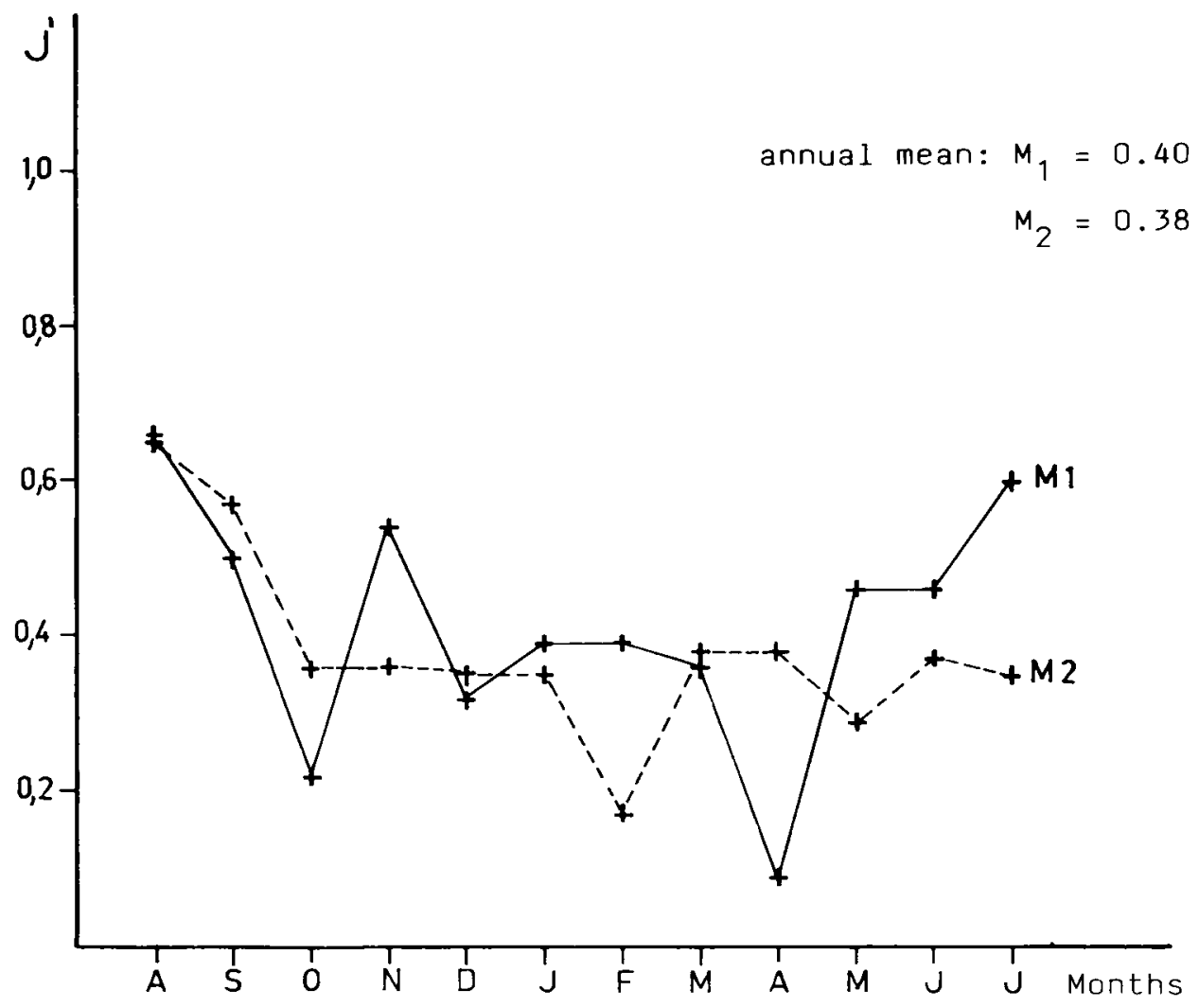

FIG. 11. - Month by month evenness $\left(J^{\prime}\right)$ of both colonies of Melipona marginata marginata - pollen.

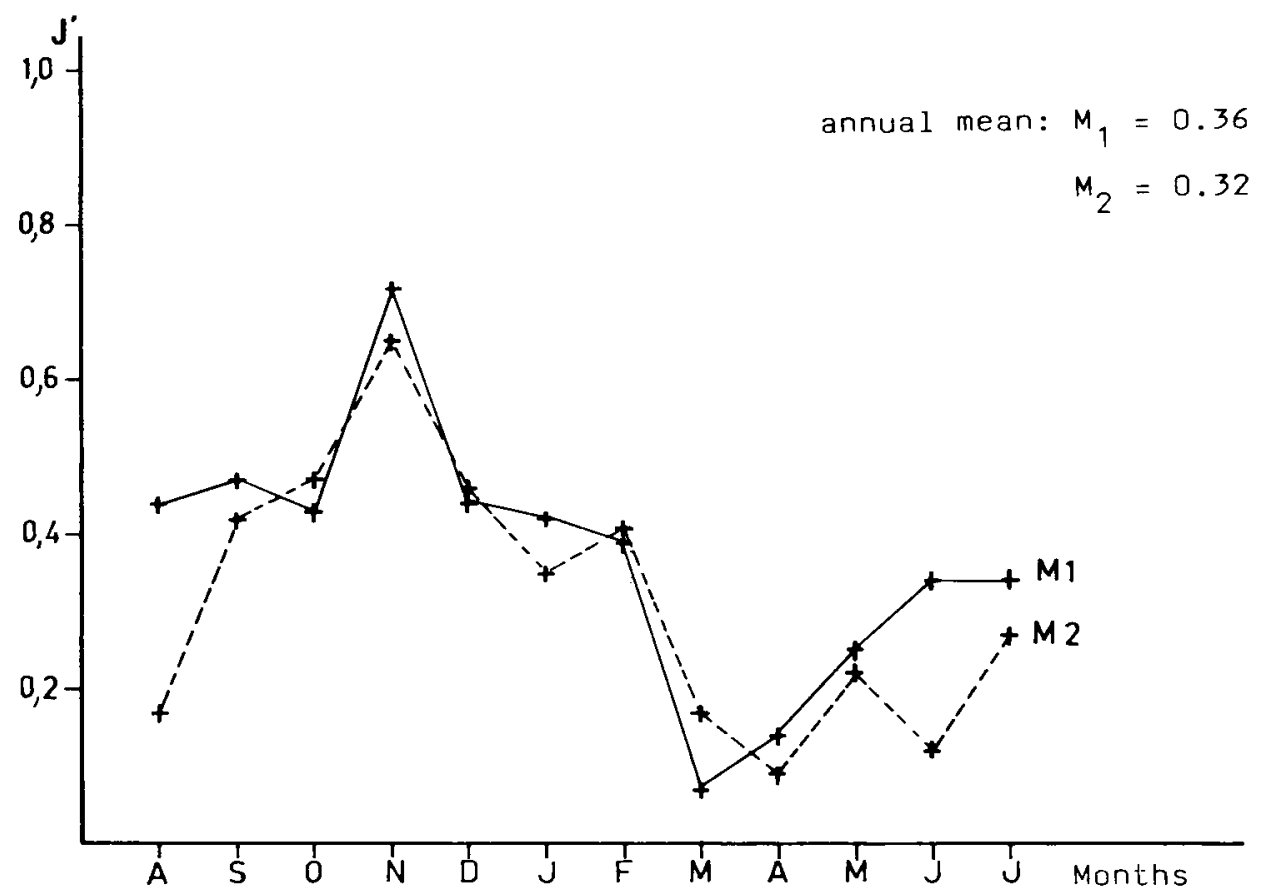

FIG. 12. - Month by month evenness $\left(J^{\prime}\right)$ of both colonies of Melipona marginata marginata - honey. 


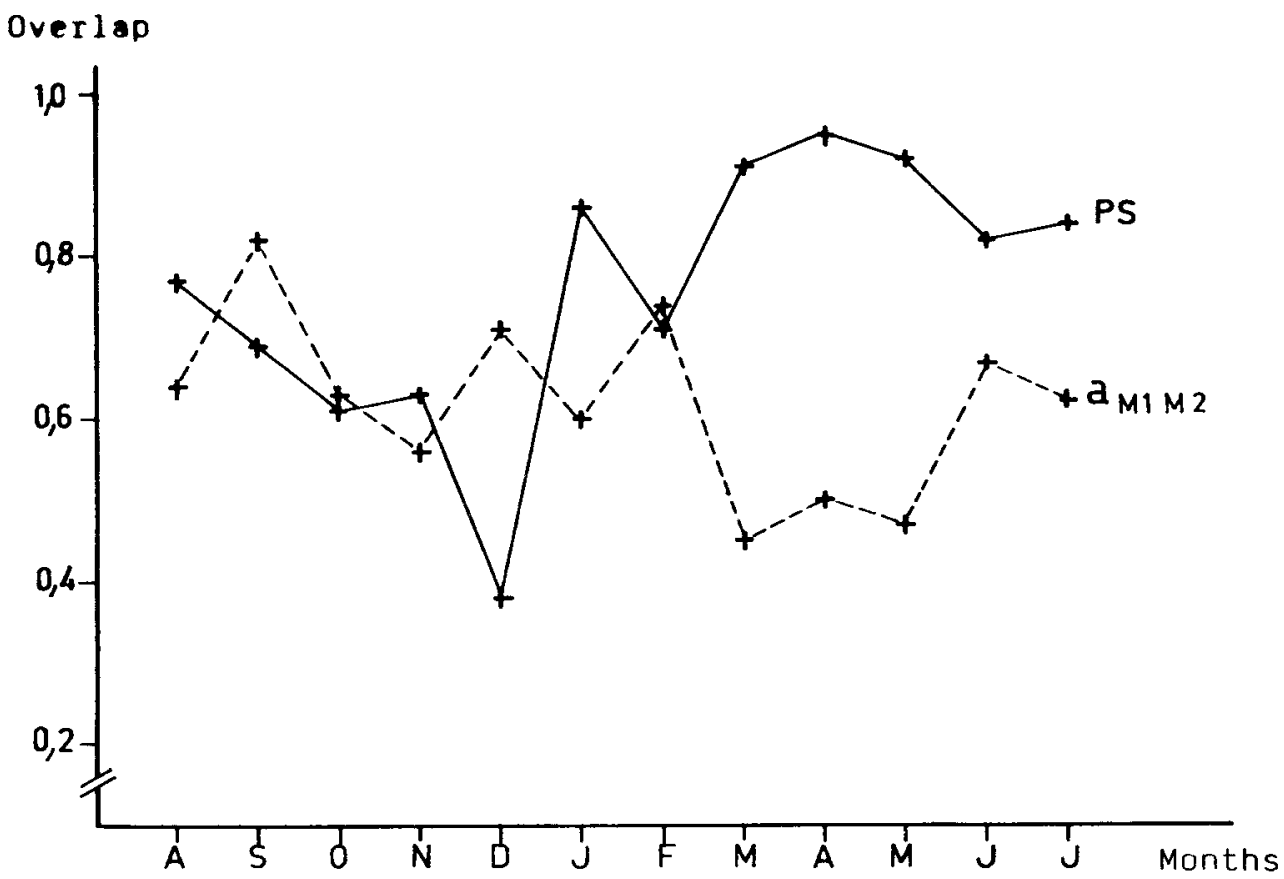

FIG. 13. - Overlap of trophic niche, as calculated according to CoDY (1974) - $a_{M_{1} M_{2}}$ - and according to SCHOENer (1968) - PS (pollen).

Fig. 13 shows the values for the overlap between the resources used to gather pollen, calculated according to CoDY $\left(\mathrm{a}_{\mathrm{M}_{1} \mathrm{M}_{2}}\right)$ and using SCHoEner's formula (PS). It can be seen that the values obtained by the two methods plot similar curves, although Schoener's index led to generally higher results. In September, December, January and February, values for overlap calculated by the second method were higher than $90 \%$, whereas the findings using Cody's method were always less than $76 \%$.

This points to the importance of considering the proportion of each plant species visited for foraging when it is possible to do so. Resource overlap as shown by CoDy's index takes into account only the total number of resources utilized, while ScHOENER's method establishes the degree of similarity between the proportions of the various pollen types found in samples. High overlap in this case means that the plant species common to both colonies were present in similar amounts, and those not found in one or the other colony were present in relatively small amounts in samples, or again that one of the species appeared with such a high percentage that the others had only a small influence on the results. 
The lowest values for overlap (PS) were found in November and June : this may mean that the plant species common to both colonies were visited in differing proportions, or that bees from the two colonies visited the plant species not visited by both to a greater extent. The annual means for overlap were as follows : 0.73 for PS, and 0.63 for $\mathrm{a}_{\mathrm{M}_{1} \mathrm{M}_{2}}$.

In order to find out whether the niche size of each colony $\left(\mathrm{H}^{\prime}\right)$ was in any way related to the percentage similarity (PS) shown in samples from both, the values obtained were correlated. No significant correlation was found between niche size $\left(\mathrm{H}^{\prime}\right)$ and similarity either for colony $\mathrm{M}_{1}(r=-0.33 ; \mathrm{P}>0.05)$ or $\mathbf{M}_{2}$ $(r=-0.01 ; P>0.05)$, in other words, there was no relation between a larger or smaller niche and the degree of similarity.

For the honey samples, in March, April and May, the highest values of PS correspondend to the lowest values of overlap calculated by the ConY method (Fig. 14). For example, in March 13 pollen types were common to both colonies ; colony $M_{1}$ foraged from 27 plant species and colony $M_{2}$ from 31. The values found for $a_{M_{1} M_{2}}$ was 0.45 . However, the sources not common to both, which were observed to be plentiful, were found in samples in low proportions. In March, Eucalyptus spp appeared with very high percentages (over $90 \%$ ) and in similar amounts in both colonies, indicating that of all the resources visited this genus was the main food source utilized and confirming the PS value for March (0.91).

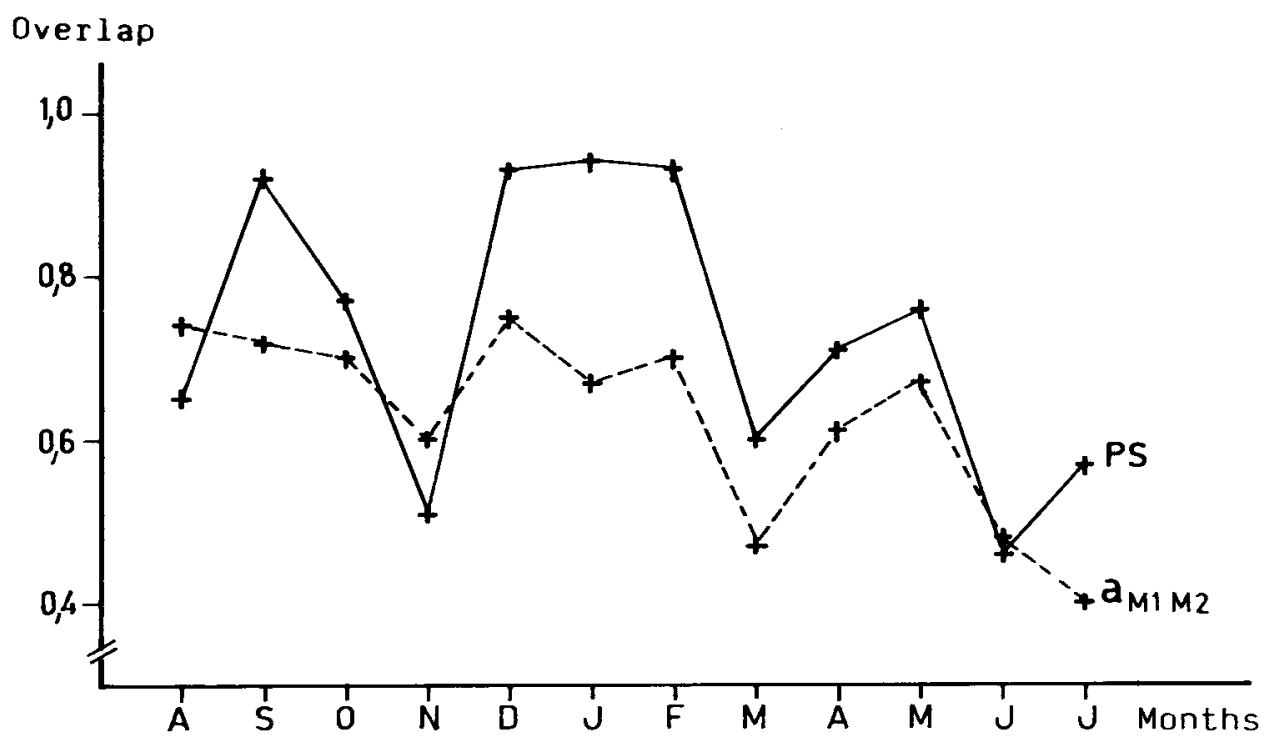

FiG. 14. - Overlap of trophic niche, as calculated according to CoDY (1974) - $a_{M_{1} M_{2}}$ - and according to SCHOENER (1968) - PS (honey). 
In December the foraging similarity index was lowest (0.38), despite the fact that the number of pollen types common to both colonies was large (16) in relation to the total number of plant species visited by colonies $M_{1}(22)$ and $\mathbf{M}_{2}$ (23), so that the CoDy index was relatively high (0.71). In December, plant species visited at higher rates by one colony had a proportionately lower representativity in the other.

No significant correlation was found $(r=-0.60 ; \mathrm{P}>0.05)$ between values of $H^{\prime}$ and PS for colony $M_{1}$. As for colony $M_{2}$, however, values of $H^{\prime}$ had a negative correlation with values of PS $(r=-0.75 ; \mathbf{P}<0.05)$ : in other words, the smaller the niche size, the larger the amount of overlap with colony $M_{1}$ in terms of the resources utilized for nectar gathering. Thus, in those months when the former colony foraged with least diversity, the plant species visited most were the same as those visited by colony $M_{1}$ at higher rates.

\section{DISCUSSION}

The number of pollen types found in samples from the two colonies of Melipona marginata marginata (173) was not very different from the amount found for Tetragonisca angustula (180) (IMPERATRIZ-FonSECA et al., 1984) and for Paratrigona subnuda (120) (MougA, 1984) in the same area. The number of plant families found for Tetragonisca angustula was 45, whereas the number of families found for Melipona marginata (32) was closer to that found by Mouga (36).

If the results for Melipona marginata are compared with those for Tetragonisca angustula found by IMPERATRIz-FonSECA (1984) and for Melipona quadrifasciata found by Guibu (personal information) on the São Paulo campus, it can be seen that the number of plant species visited for nectar $(124,158$, and 86 respectively) was higher than that found in the pollen samples $(105,140$, and 36), and that the same is true for each colony in isolation.

Arsy and Kerr (1977) and Arsy et al. (1980) studied bees in the Amazon, and observed the same with regard to samples from Melipona seminigra merrilae (33 species for pollen gathering, and 49 for nectar). In 1929, RobERTson had already mentioned that although many bees limit their pollen collecting to a small number of plant species, they obtain nectar from a large variety of plants, although this difference many not appear clearly in the food samples. He therefore suggested that only pollen collecting be considered when determining relations between bees and flowers. Thus, Michener (1979) used the term broadly polytectic to refer to species which collect pollen from many unrelated plant species. Species which limit pollen gathering to a few related plant species, usually from the same genus (or even the same species), are 
called oligolectic (or monolectic). According to Michener, it may be presumed that most bee species collect pollen from various plant species (which are not necessarily related) in the greater part of the communities in which they live, presenting a variation in the plant species visited in terms of locality and season. These he called narrowly polytectic.

Melipona marginata can be placed in the latter of these categories (narrowly polytectic), for even if only the pollen types with more than $1 \%$ representativity are considered, along with those present with percentages of more than $10 \%$ in pollen samples, it can be seen that the plant species found in these samples belong to a relatively large number of plant families.

Cortopassi-Laurino (1982) also noted a high frequency of pollen types with less than $1 \%$ in samples of pollen from Apis mellifera and Trigona spinipes, although the amount of pollen types with this representativity was larger than that found in pollen samples from the two colonies of Melipona marginata studied here. Mouga (1984) found the same in her pollen samples from Paratrigona subnuda.

The presence of a large number of pollen grains with extremely low representativity may be due to various factors, such as contamination by the bees themselves during foraging, and, later on, during food processing ; the presence of anemophilous pollen ; or a sampling error (improbable, as this fact was verified in all the stingless bees and Apis mellifera colonies kept in the same place as the site for this study).

A further suggestion is that these pollen grains may represent potential food sources (in this case, those with less than $10 \%$ representativity could also be included), used when more attractive blooms are not available, or even that chance plays a part in the localization of source. It is easy to imagine that foragers leaving a colony to gather food spread out among the flowers at random. On their return to the colony, they communicate the existence or absence of a rewarding bloom, so that only if the answer is positive do a large number of individuals leave the colony for the site found. If several foragers go out in search of food and constantly return with negative information for a longer period, however, the number of plant species with low percentages present in combs or food pots must be very large.

The pollen types represented with more than $10 \%$ were considered the really important sources for pollen and/or nectar gathering during the period analyzed. The small number of plant species with this level of representativity in samples from both colonies corroborates the idea expoundend above. However, the two colonies studied showed a high percentage of visits to sources which (with the exception of Eucalyptus spp) are not normally important for Apis or for other stingless bees (such as Solanum and Psidium 
guayava) in this region, thus suggesting a specific foraging approach, or the fact that other bees were forcing them away from more attractive resources, especially Apis mellifera.

Melipona quadrifasciata, another species of this genus which is present in the area studied, also visited these less exploited species at high rates (Guibu, personal information).

It can be assumed that Apis mellifera forces Melipona marginata foragers away from the sources they consider attractive, and that the latter are obliged to look for other sources or to reduce the time they spend foraging in places where Apis is numerous. This hypothesis has been tested by RouBIK (1978) in French Guiana, where he found that as the number of Apis using a given food source increased Melipona spent less time foraging in the same place. This author did not observe any aggressive interaction between these bees when foraging from flowers. In another paper, RouBIK (1980) remarked that Melipona fulva abandoned feeders when disturbed by agressive species such as those of the genus Trigona.

Eucalyptus spp, which is found to a great extent in samples from eusocial bees living on the campus of São Paulo University (Iwama and Melhem, 1979 ; Cortopassi-Laurino, 1982 ; Mouga, 1984 ; Imperatriz-Fonseca et al., 1984 ; RAMALHO et al., 1985), is represented by a large number of individuals on this site. It can be assumed that pollen and nectar production is high enough for the local bee community to exploit it without the need for any species to force another away from food sources. It must be pointed out, however, that species of this genus are overrepresented in honey samples (BARTH, 1970). In samples from Melipona marginata and the other species of bees analyzed (Cortopassi-LAURINo, 1982 ; Mouga, 1984 ; ImPERATriz-Fonseca et al., 1984), this genus was also important for pollen gathering.

Sommeijer (1983) in Suriname found that the various colonies of Melipona scutellaris and Melipona favosa from which pollen samples were analyzed made very frequent visits to Psidium guayava, one of the species used virtually only by Melipona marginata and Melipona quadrifasciata (GuiBu, personal inf.).

Two species belonging to the genus Solanum were highly represented in several pollen samples from both colonies of Melipona marginata. As for honey samples, only one of the species was found with a percentage of more than $10 \%$. The same species were abundant in pollen and honey samples from Melipona quadrifasciata (Guibu, personal inf.). For Paratrigona subnuda (Mouga, 1984), Apis mellifera (Cortopassi-Laurino, 1982), and Tetragonisca angustula (IMPERATRIz-Fonseca, et al., 1984), however, these species were not found or were very sparsely represented in samples. IwAMA and MELHEM 
(1979) found one species of this genus at high rates only in one of the honey samples from Tetragonisca angustula obtained from the same site.

Solanum has tubular anthers, and only large bees which can shape the anthers or invert the flowers are skilful enough to obtain large amounts of pollen in a short space of time (SYMON, 1979).

Michener (1962) found that large and medium-size bees belonging to various systematic groups produced intermittent vibrating sounds when collecting pollen from certain flowers with tubular anthers, which opened up to the outside through apical pores. The bees obtained pollen through these vibrations, which produced a loud sound and made the pollen grains come out through the pores in the anthers. He also remarked that the potential for learning this method must be innate to certain groups of bees. The same author observed small bees removing tiny amounts of pollen, probably left behind by large bees on the apex of the anthers around the openings in Solanum.

The family Melastomataceae also has species with this type of anther, and two of these (Tibouchina spp and Miconia type) were important for Melipona marginata. They were also abundant in samples from Melipona quadrifasciaca (Guibu, personal inf.).

Another species of importance for Melipona marginata is Mimosa daleoides, used both for pollen and nectar : this is a very common ruderal plant species all over the campus in question and the immediate environs. It was also abundant in samples from Tetragonisca angustula (IMPERATrIz-FonsECA et al., 1984), although Iwama and Melhem (1979) only found it with higher percentages a single time in their honey samples. This species was not representative in samples from the other bees in the area (Cortopassi-LaURINO, 1982 ; MougA, 1984).

Some plant species were well represented in pollen samples from both colonies but were not visited very much for nectar, such as Myroxylon balsamum and Morus nigra. The former was also found at high rates only in pollen samples from Paratrigona subnuda (Mouga, 1984). Morus nigra was visited for pollen by both $P$. subnuda (MougA, op. cit.) and $T$. angustula, but it was also important for the latter species for nectar (IMPERATRIz-Fonseca et al., 1984).

The reverse was also observed : some species present in honey samples were not so highly represented in pollen samples, such as Alchornea sidaefolia and Leguminosae 1. The former species, found only once with more than $10 \%$, was one of the most important plant species for pollen and nectar gathering for $T$. angustula (Imperatriz-Fonseca et al., 1984). Iwama and MeLhem (1979) found another species of this genus which was represented in honey samples from the same bee in the same area. 
The other plant species were highly represented in both types of sample. Proctor and Yeo (1979) observed that pollen and nectar gathering from the same flower is common behaviour among social bees, and that generally speaking there is a special preference for flowers which provide both pollen and nectar.

The larger number of pollen types represented less than $10 \%$ in honey samples may be related to the fact that the bees had to look for more sources of nectar before they could find one that satisfied the colony's need, whereas the amount of pollen supplied by the plant species was mostly sufficient for the colonies. Melipona marginata has colonies with relatively small populations (400 - 500 individuals), and its food requirements are far smaller than those of colonies of $T$. spinipes, for example, which may have as many as 5000 180000 bees (Lindauer and KerR, 1960).

It was also possible to note a difference between colonies as regards the proportion of plant species visited, especially for nectar, and there was a difference in the number of pollen types present with less than $10 \%$ representation.

For both colonies, the number of plant species which were important for pollen gathering was the same (9), whereas the number of plant species with more than $10 \%$ representativity used for nectar gathering was lower in colony $M_{1}$ (5) than $M_{2}(8)$.

Colony $M_{1}$ was stronger than $M_{2}$, i.e. it had more combs, more food pots and more population. A stronger colony needs more food, and thus has to be more efficient in its search for sources which provide an adequate reward. Moreover, strong colonies usually have larger bees, which are better equipped to carry loads for the colony.

As regards the plant families most visited for foraging purposes, and those presenting the largest numbers of plant species used for foraging, it was found that although the family Leguminosae had the largest number of species, the importance of this family as a food source was far less than that of the family Myrtaceae. Of the 14 species of Leguminosae visited, Mimosa daleoides and Myroxylon balsamum were the only sources which were highly exploited by Melipona marginata.

The family Compositae, the second most represented in terms of number of species in samples, was visited only sporadically by both colonies. For CORTOPASSI-LAURINo (1982), this family was ranked third in terms of its percentage occurence in pollen samples from Apis mellifera and Trigona spinipes.

It can be assumed that limiting foraging to one or a few species from a given plant family which is well represented by a large number of species 
shows that these resources are being used in preference to others, or that more efficient competitors are forcing the bees in question away from other resources. Thus, less aggressive species such as Melipona marginata seem to focus on plant species which are less visited by other bees and on families whose members need a certain degree of foraging specialization or skill.

The major exception was the family Myrtaceae, visited by all the eusocial bee species in the region (Cortopassi-Laurino, 1982 ; MougA, 1984 ; ImperaTRIz-Fonseca et al., 1984). Eucalyptus spp which is very abundant in the area, accounted for practically all foraging from species in this family. It is interesting to note that the next most frequent species, Psidium guayava, was the most visited by two species of Melipona in Suriname, as mentioned above (Someijer et al., 1983), and that in the area studied in this case Eucalyptus was not present. It may well be, therefore, that bees of this genus really have a certain preference for a given family, for none of the other species studied by SommeIJer, including Apis mellifera, gathered much food from this plant species. Another interesting point is that from all the visited plant species, the most represented in both type of samples were trees. This was also observed in the food samples of $P$. remota at the same site of this study (RAmalHo et al., 1985), suggesting a kind of specificity in relation to food gathering.

The variation observed in the niche size of Melipona marginata obviously reflects the results of the interaction between the foraging strategies of all the species living in the area. As pointed out in the section on results, niche size as indicated by the number of pollen types fails to highlight the relative importance of plant species visited for food and assumes utilization of resources to be homogeneous. The positive correlation between number of pollen types and diversity index, found only in pollen samples from colony $\mathbf{M}_{2}$, was the result of a concentration of values in the range between 0.80 and 1.20 , for niche size calculated according to SHAnnon-Weaver's index $\left(\mathrm{H}^{\prime}\right)$. These samples represented $25 \%$ of the total analyzed; no correlation was found in the others.

Camillo (1983) noted a positive correlation between values for niche size obtained by one and the other method for both species of Bombus studied. The methodology used by this author, however (analysis of loads collected in the worker's corbiculae), was different from ours, and it must also be remembered that this study was conducted 250 miles away from our area (in Ribeirão Preto).

As already pointed out (see results section), most of the time there was no correspondence between diversity and number of pollen types found, and this was clearest in the honey samples: the month in which the number of plant species visited for nectar was highest corresponded precisely to the lowest calculated value for diversity. 
Niche size, as calculated by SHANNON-WEAver's diversity index, was positively correlated with evenness in both pollen and honey samples for both colonies. This was as expected, although other authors have not found the same result (Ranta et al., 1981 ; Camillo, 1983).

Having made this reservation, let us merely compare maxima and minima for diversity and evenness obtained by some authors who have worked in tropical regions (Cortopassi-Laurino, 1982 ; Camillo, 1983 ; Mouga, 1984) with our results for pollen samples : this should provide an idea of the degree of specificity in foraging among the bees considered.

\begin{tabular}{|c|c|c|c|c|}
\hline \multirow[b]{2}{*}{ Species } & \multicolumn{2}{|c|}{$\mathbf{H}^{\prime}$} & \multicolumn{2}{|c|}{$\mathbf{J}^{\prime}$} \\
\hline & $\begin{array}{c}\text { Value } \\
>\end{array}$ & $\begin{array}{c}\text { Valuc } \\
<\end{array}$ & $\begin{array}{c}\text { Valuc } \\
>\end{array}$ & $\begin{array}{c}\text { Value } \\
<\end{array}$ \\
\hline B. atratus & 2.18 & 0.57 & 0.94 & 0.36 \\
\hline B. morio & 2.69 & 0.66 & 0.89 & 0.43 \\
\hline (CAMILlo, 1983) & & & & \\
\hline Apis mellifera & 2.51 & 0.83 & 0.70 & 0.31 \\
\hline$T$. spinipes & 2.21 & 0.89 & 0.66 & 0.28 \\
\hline (CorTOPASSI-LAURINO, 1982) & & & & \\
\hline P. subnuda & 1.58 & 0.67 & 1.00 & 0.30 \\
\hline (MOUGA, 1984) & & & & \\
\hline M. marginata & & & & \\
\hline $\mathrm{M}_{1}$ & 1.52 & 0.22 & 0.66 & 0.09 \\
\hline $\mathrm{M}_{2}$ & 1.49 & 0.17 & 0.65 & 0.09 \\
\hline
\end{tabular}

As regards niche size, it can be seen that the colonies of Melipona marginata had lower values than any other bee species, i.e. sometimes concentrated its foraging intensely on one single plant species and only visited other food sources inconspicuously. Values as low as these were not found for any other species. Maximum values of diversity were comparable only with those for $P$. subnuda.

On the other hand, $A$. mellifera and $T$. spinipes had far higher maximum values than these, and values which were comparable with those obtained for the two species of Bombus. This difference in diversity may be due to differing foraging strategies used by the various bee species in order to achieve greater efficiency in using the available resources, in view of the different energy needs of each species.

Of all the species concerned, $M$. marginata with its smallest colonies has nothing to gain from consuming energy and time in a battle with other species for any given food source; the loss of a few foragers is significant for this species. This may also explain the high percentage of foraging from plant 
species of the families Solanaceae and Melastomataceae, which are not commonly visited by other bees.

$P$. subnuda, however, has more numerous colonies than $M$. marginata, but they are far less populous than those of $A$. mellifera and $T$. spinipes, which can have up to about 80000 individuals. When the two latter species visit the same plant, they spread out on blossoms in accordance with their density : Apis goes to the denser blooms and $T$. spinipes to the less densely flowered plants (Martins, 1985). The monopolistic foraging strategy used by these two species probably leads other stingless bees in the area which do not have such as elaborate strategy to limity their foraging to sources which are not exploited by these bees or to visit them only when the latter have gone away (or at least when there are fewer bees collecting) to some other more attractive source.

Melipona marginata also showed the lowest evenness value, which was expected because of the positive correlation between this index and $\mathbf{H}^{\prime}$, i.e. it was the species which used the sources visited least homogeneously. It can be seen that of all the species studied within the university campus, $M$. marginata and $P$. subnuda showed the highest difference between the extreme values, showing greater variability in the way they used food resources, probably as a result of the foraging strategy used by $A$. mellifera and $T$. spinipes.

If the two colonies of $M$. marginata are considered, summer was the season when they showed the greatest similarity in terms of the sources visited for pollen. It can be supposed that at that time few preferentially visited plant species are in flower or available, so that the two colonies do not have the option to use resources differently.

As far as honey samples are concerned, autumn and early winter were the times when the two colonies overlapped most. At this time, they foraged an enormous amount from Eucalyptus spp, and the high degree of similarity was due mainly to the large representation of this genus in samples.

Received for publication in November 1985.

Accepted for publication in September 1986.

\section{ACKNOWLEDGEMENTS}

We wish to thank D' Therezinha S. Mel.hem for the technical advice and also Fundação de Amparo à Pesquisa do Estado de São Paulo (FAPESP - $n^{\circ}$ 81/1531-7) for providing financial assistance. 


\section{RÉSUMÉ}

\section{ASPECTS DE LA NICHE TROPHIQUE DE MELIPONA MARGINATA MARGINATA LEPELETIER (APIDAE, MELIPONINAE)}

Des échantillons de pollen et de miel ont été prélevés dans les pots à nourriture de deux colonies de Melipona marginata marginata $\left(\mathrm{M}_{1}\right.$ el $\left.\mathrm{M}_{2}\right)$ une fois tous les 15 jours durant une annce (d'août 1981 à juillet 1982). Au total 95 échantillons ont été prélevés. 48 de miel et 47 de pollen.

Durant les 12 mois de récolte on a trouvé 173 types polliniques appartenant à 32 familles de plantes, 105 provenant des échantillons de pollen et 125 de ceux de micl. Sculs 26 types de pollen (14 dans les échantillons de pollen et 25 dans ceux de micl), appartenant à 15 familles botaniques, étaient présents en pourcentages supérieurs à $1 \%$. Sur ces 26 types, seulement 11 types (9 dans les échantillons de pollen et 8 dans ceux de micl), appartenant à 6 familles, avaient une représentativité supéricurc à $10 \%$ (Tabl. 1). Parmi toutes les espèces visitées, les plus représentées dans les deux types d'échantillons sont des arbres.

Dans les colonics $M_{1}$ et $M_{2}$ les échantillons de pollen comportent les mêmes neuf types polliniques. seule leur représentativité mensuclle varie : Eucalyptus spp, Psidium guayava, Solanum spl. Solanum sp2. Tibouchina spp, Miconia type, Mimosa daleoides, Myroxylon balsamum et Morus nigra (Fig. 1 ct 2).

Dans les échantillons de micl de la colonic $M_{1}$, on a trouvé 5 espèces ayant une représentativité supérieure à $10 \%$, et dans ceux de la colonic $M_{2}, 8$ espèces. Les types polliniques suivants ont été trouvés dans les deux colonics : Eucalyptus spp, Psidium guayava, Solanum sp1, Tibouchina spp, Mimosa daleoides. La colonic $\mathbf{M}_{2}$ renfermait en outrc Ics trois types polliniques suivants : Alchornea sidaefolia, Leguminosac 1 el Miconia type (Fig. 3 et 4). Le nombre de types polliniques ayant une représentativité inférieure à $10 \%$ est significativement plus élevé dans les échantillons de pollen tout au long de l’annéc, prouvant que les abeilles visitent un plus grand nombre de plantes pour le nectar jusqu'à ce qu'clles se fixent à une ou quelques espèces qui pourront combler leurs besoins.

Les Légumincuses, les Composées, les Euphorbiacées et les Myrtacées sont les familles botaniques représentées dans les échantillons de pollen et de miè par le plus grand nombre d'esnèces (Fig. 5). Si Pon tient compte du pourcentage d'occurrences, ce sont les Myrtacées qui sont le plus visitécs pour le pollen et le nectar, suivies par les Solanacées. Puis viennent les Mélastomatacées et les Légumineuses pour le pollen et ces mêmes familles, mais dans l'ordre inverse, pour les ćchantillons de miel.

La taille de la niche, évaluée par le nombre de types de pollens. ne permet pas de mettre en évidence l'importance relative des espèces de plantes butinćes et indique unc utilisation homogène des ressources (Fig- 7 et 9).

En ce qui concerne la taille de la niche, calculée daprès lindice de diversité de Shannon-Weaver. les deux colonics ont des valcurs inféricures à tout autre espèce d’abcille de la même région et utilisent les sources visitées de la façon la moins homogène (Fig. 8, 10, 11 et 12).

L'été est la saison où les deux colonies présentent la plus grande similitude en termes de sources visitées pour le pollen (Fig. 13). Dans la mesure où les échantillons de miel sont concernés, l'automne et lhiver sont les périodes où les deux colonics se chevauchent ke plus (Fig. 14).

\section{ZUSAMMENFASSUNG}

\section{ASPEKTE DER TROPHISCHEN NISCHE VON MELIPONA MARGINATA MARGINATA} LEPELETIER (APIDAE, MELIPONINAE)

Ein Jahr lang (August 1981 bis Juli 1982) wurden alle zwei Wochen aus den Futtertōpfen von zwei Völkern von Melipona marginata marginata Lep. $\left(M_{1}\right.$ und $\left.M_{2}\right)$ Pollen- und Honigproben entnommen. Insgesamt wurden 95 Proben gesammelt, 48 Honig- und 47 Pollenproben. 
Während der Sammelperiode von 12 Monaten wurden in den Pollen- und Honigproben 173 Pollentypen gefunden, die zu 32 verschiedenen Pflanzenfamilien gehörten. Von diesen wurden 105 zum Pollensammeln und 125 zum Nektarsammeln genutzt. Nur 26 Pollentypen (14 in den Pollen- und 26 in den Honigproben) aus 15 Pflanzenfamilien wurden in einer Häufigkeit von über $1 \%$ gefunden. Von diesen 26 waren nur 11 Typen ( 9 in den Pollen- und 8 in den Honigproben) aus sechs Familien zu über $10 \%$ vertreten. Es ist interessant, daß bei beiden Probenarten die am stärksten vertretenen Pollentypen von Bäumen stammten.

In den Kolonien $M_{1}$ und $M_{2}$ wurden dieselben neun Pollentypen als Pollen gesammelt, nur der monatliche Anteil variicrte in den Proben: Eucalyptus spp, Psidium guayava, Solanum sp.1, Solanum sp. 2, Tibouchina spp., Miconia-Typ, Mimosa daleoides, Myroxylon balsamum und Morus nigra (Abb. 1 und 2).

In Honigproben von Volk $M_{1}$ wurden fünf Pflanzenarten und in Volk $M_{2}$ acht Arten mit einem Anteil von mehr als $10 \%$ gefunden. Folgende Pollentypen waren beiden Völkern gemeinsam : Eucalyptus spp., Psidium guayava, Solanum sp.1, Tibouchina spp. und Mimosa daleoides. Volk $\mathrm{M}_{2}$ enthielt drei weitere Pollentypen: Alchornea sidaefolia, Leguminosae 1 und Miconia-Typ (Abb. 3 und 4). Die Zahl der Pollentypen mit einer Repräsentanz von weniger als $10 \%$ war das ganze Jahr über in den Honiproben signifikant höher als in den Pollenproben, was darauf hinweist, daß die Bienen eine größere Anzahl von Pflanzen auf der Suche nach Nektar anflogen, bis sie konstant bei einer oder mehreren Arten blicben, welche ihren Bedarf decken konnten.

Dic in den Proben am häufigsten vertretenen Pflanzenfamilien waren im Pollen wic im Honig dic folgenden : Leguminosae, Compositae, Euphorbiaceae und Myrtacea (Abb. 5). Wird die Häufigkeit des Auftretens berücksichtigt, so wurden Myrtaceac für Pollen wic für Nektar am stärksten besucht, gefolgt von Solanaccac. Die nächst häufig besuchten Familien waren Melastomataceae und Leguminosac für Pollen ; im Honig waren dieselben Familien in umgekehrter Reihenfolge vertreten (Abb. 9).

Die Nischengröße, wie sie durch die Zahl der Pollentypen angezeigt wird, läßt keine bestimmte Pflanzenart von relativer Bedeutung für die Futterversorgung hervortreten, sondern sie deutet auf cine glcichmäßige Nutzung der Resourcen (Abb. 7. 8).

Was die Nischengröße betrifft, berechnet nach dem Diversitäts-Index nach SHaNnON-WEAVER, So hatten beide Völker niedrigere Werte als alle anderen Bienenarten desselben Gebietes und sie nutzten dic besuchten Futterquellen am wenigsten gleichmäßig (Abb. 8, 10, 11, 12). Im Sommer zeigten beide Völker die größte Übercinstimmung in der Nutzung der Pollenspender (Abb. 13). Bei den Honigproben überlappten beide Kolonien im Herbst und Winter am stärksten (Abb. 14).

\section{REFERENCES}

Absy M.L. and Kerr W.E., 1977. - Algumas plantas visitadas para obtençăo de pólen por operárias de Melipona seminigra merrilae em Manaus. Acta Amazônica, 7 (3), 309-315.

Absy M.L., Bezerra E.B. and Kerr W.E., 1980. - Plantas nectaríferas utilizadas por duas espécies de Melipona da Amazônia. Acta Amazônica, 10 (2), 271-282.

Barth M.O., 1970. - Análise microscópica de algumas amostras de mel : 1 : pólen dominante. An. Acad. brasil. Ciên., 42 (2), 351-366.

Cаmillo E., 1983. - Consideraçōes sobre a ecologia de duas espécies simpátricas de Bombus (Hymenoptera, Bombinae O. PhD. Thesis. Departamento de Ciências Biológicas. Universidade Federal de São Carlos. Sāo Carlos (SP). 118 p.

Cody M.L., 1974. - Competition and the structure of bird communities. - New Jersey Princeton Univ. Press. 318 p.

Cortopassi-Laurino M., 1982. - Divisão de recursos tróficos entre abelhas sociais, principalmente em Apis mellifera Linné e Trigona (Triogona) spinipes Fabricius (Apidae, Hymenoptera). PhD. Thesis. Instituto de Biociências. Universidade de São Paulo. São Paulo, 180 p. 
Darwin C.R., 1859. - The origin of species. - London, Collicr-Macmillan Ltd., 512 p., 1962.

Engei. M.S. and Dingemans-Bakels F., 1980. - Nectar and pollen resources for stingless bees (Meliponinae, Hymenoptera) in Surinam (South America). Apidologie, 11 (4), 341-350.

Erdtman G., 1960. - The acetolysis method - A revised description. Svenk bot. Tidskr., 54 (4), 561 564.

Hubbell S.P. and Johnson L.K., 1977. - Competition and nest spacing in a tropical stingless bee community, Ecology, 58, 949-963.

Hubbell S.P. and Johnson L.K.. 1978. - Comparative foraging behavior of six stingless bee species exploiting a standardized resource. Ecology, 59 (6), 1123-1136.

Hutchinson G.E., 1957. - Concluding remarks. Cold Spring Harb. Symp quant. Biol., 22, 415-427.

Imperatriz-Fonseca V.L., Kleinert-Giovannini A., Cortopassi-Laurino M. and Ramalho M., 1984. Hábitos de coleta de Tetragonisca angustula angustula Latreille (Hymenoptera, Apidae, Meliponinae). Bol. Zool. Univ. S. Paulo, 8, 115-131.

IWAma S. and Melmem T.S., 1979. - The pollen spectrum of the honey of Tetragonisca angustula angustula Latreillc. Apidologie, 10 (3), 275-295.

Johnson L.K. and HubBell S.P., 1974. - Agression and competition among stingless bees : ficld studies. Ecology, 55, 120-127.

JohnSoN L.K. and HubBelL S.P., 1975. - Contrasting foraging strategies and coexistence of two bee species on a single resource. Ecology, 56, 1398-1406.

Kerr W.E., Absy M.L. and Souza A.C.M., 1984. - Flora visitada pela abelha Melipona compressipes fasciculata no Maranhăo. Ciênc. e Cult. (suppl.), S. Paulo, 36 (7), 905-906.

Knol.t. F.R.N., 1985. - Abundância relativa das abelhas no Campus da Universidade de Säo Paulo (23" $33^{\prime} \mathrm{S} ; 46^{\prime \prime} 43^{\prime} \mathrm{W}$ ), com especial referência à Tetragonisca angustula Latreille. MSc Thesis. Instituto de Biociências. Universidade de São Paulo. São Paulo, 79 p.

Levins R., 1968. - Evolution in changing environments : some theoretical explorations. Princeton Univ. Press, $120 \mathrm{p}$.

Lindauer M. and Kerr W.E., 1960. - Communication between the workers of stingless bees. Bee Wld., 41, 29-41.

Louveaux J., Maurizio A. and Vorwohl. G., 1970. - Methods of melissopalinology. Bee Wld., 51 (3). 125-138.

MacArthur R.H., 1968. - The theory of the niche. In : Population biology and evolution. - Syracuse, Syracuse Univ. Press, p. 159-176.

MARTINS C.F., 1985. - Abundância relativa de abelhas sociais em floradas de algumas monoculturas. MSc. Thesis. Instituto de Biociências. Universidade de São Paulo. São Paulo, 132 p.

Michiner C.D., 1962. - An interesting method of pollen collecting by bees from flowers with tubular anthers. Rev. Biol. trop., 10 (2), 167-175.

Michener C.D., 1979. - Biogeography of the bees. Ann. Mo. Gdn., 66 (3), 227-347.

Mouga D.M.D.S., 1984. - Atividade de coleta de Paratrigona subnuda (Moure) (Apidae, Meliponinae). MSc Thesis. Instituto de Biociências. Universidade de São Paulo. São Paulo, 117 p.

Nogueira-Neto P., 1970. - - A criação de abelhas indigenas sem ferrão. 2nd ed. - São Paulo, Ed. Chácaras e Quintais, $365 \mathrm{p}$.

Pianka E.R., 1976. - Competition and niche theory. In : Theoretical ecology : principles and applications. - Blackwell Scientific Publications, Oxford, p. 114-141.

Pielou E.C., 1977. - Mathematical ecology. 2nd ed. - New York, Willey-Interscience publication John Wilcy and Sons, $385 \mathrm{p}$.

Proctor M. and YEO P., 1979. - The pollination of flowers. - Glasgow, William Collins Sons and Co. Lid., $418 \mathrm{p}$.

Ramalho M., Imperatriz-Fonseca V.L., Kleinert-Giovannini A. and Cortopassi-Laurino M., 1985. Exploitation of floral resources by Plebeia remota (Holmberg) (Apidae, Mcliponinae). Apidologie, 16 (3), 307-330. 
Ramalho M. and Kleinert-Giovannini A.. in press. - Frequency classes in honey and pollen samples an ccological approach. Bol. Ecol.

Ranta E., Lundberg H. and Teräs I., 1981. - Patterns of resource utilization in two Fennoscandian bumblebec communities. Oikos, 36, 1-11.

Robertson C., 1929. - Phenology of oligolectic bees and favorite flowers. Psyche, 36, 112-118.

Roubik D.W., 1978. - Competitive interactions between neotropical pollinators and Africanized honcybees. Science, 201, 1030-1032.

Roubik D.W., 1979. - Africanized honeybees, stingless bees and the structure of tropical plantpollinator communitics. Proc. IVth. Int. Symp. on Pollination. Md. Agric. Exp. Sta. Spec. Misc. Publ., Maryland, 1, 403-417.

RoubIK D.W.. 1980. - Foraging behavior of competing Africanized honeybecs and stingless bees. Ecology, 61, 836-845.

SChoener T.W., 1968. - The Anolis lizards of Bimini : resource partitioning in a complex fauna. Ecology, 49, 704-726.

ShANNON C.E. and WeAver W., 1949. - The mathematical theory of communication. - Urbano, Univ. of Illinois Press. $117 \mathrm{p}$.

Sommeijer M.J., Rooy G.A. de, Punt W. and Bruinn L.L.M. de, 1983. - A comparative study of foraging behavior and pollen resources of various stingless bees (Hym., Meliponinae) and honeybees (Hym., Apinac) in Trinidad, West-Indies. Apidologie, 14 (3), 205-224.

Symon D.E., 1979. - Sex form in Solanum (Solanaceae) and the role of pollen collecting insects. In : Hawkes J.G., Lester R.N. and Skelding A.D., The biology and taxonomy of the Solanaceae. London. Acadcmic Press, 738 p.

Vandermefr J.. 1972. - Niche thcory. Annu. Rev. Ecol. Syst., 3, 107-132.

VERGERON P., 1964. - Interprétation statistique des résultats en matière d'analyse pollinique des miels. Ann. Abeille, 7 (4), 349-364. 